\title{
BRIGITTE AND THE FRENCH CONNECTION: SECURITY CARTE BLANCHE OR A LA CARTE?
}

\author{
GREg CARNE
}

[ The October 2003 deportation of French terror suspect Willy Brigitte highlights the legal and political usages of recently conferred and controversial counterterrorism detention and questioning laws. This article explores the executive contention upon a comparison with the French system, Australian detention and questioning powers require significant expansion. Executive usages of the Brigitte incident in response to terrorism display alarming trends steadily eroding rule of law principles and undermining the institutions and practices of Australian democracy.

The article analyses ASIO detention and questioning powers and subsequent and possible expansions. It demonstrates that the constant review, re-working and revisiting of those powers is a more overt politicisation of counter-terrorism responses, employs executive mandated review at the expense of more measured, deliberative and democratic practice and leads to the attrition of rights as the legislation's "balance" is continually contested. The indefinite nature of the terrorism threat and the restraint on such responses as political only, in the absence of a bill of rights, makes these developments of real concern. The article argues, through several illustrations, that claims for expanded detention and questioning powers have been inappropriately presented. The article concludes that there is neither a rational nor substantiated case for the claim to loosen constraints on already unprecedented counter-terrorism detention and questioning powers.]

\footnotetext{
* Lecturer, Faculty of Law, University of Tasmania. The author would like to thank Professor George Williams, Director of the Gilbert and Tobin Centre for Public Law, Faculty of Law, University of New South Wales for his comments on a draft of the article and Simon Bronitt, Reader in Law and Director of the National Europe Centre, Australian National University, for some observations on an early draft and the anonymous referees for their comments.
} 
I'm saying that we do not have the powers that they have in France to be able to detain people for the purposes of questioning, that they have in France. That's the only point I'm making. The powers that we have, have been significantly circumscribed by the requirements that the Parliament sought when the legislation was debated. ${ }^{1}$

The cooperation between Australia and France in relation to Brigitte clearly worked. It has clearly been successful...I would say that was a pretty good outcome, mon ami. $^{2}$

It might be a campaign also to support the legislation in Australia. The Australian might want to come out with a law or something to reduce the right of defence, to reduce the liberty and they might take the Brigitte case as a threat that is flowing over Australia, and justify all restrictions to human rights... ${ }^{3}$

\section{INTRODUCTION}

\section{A The factual background of the Brigitte incident}

The arrest and deportation in October 2003 of French national Willy Brigitte, alleged to have been involved in the planning of unspecified terrorist activities in Sydney and having links to al-Qaeda, has generated intense and continuing interest in the effectiveness of counter-terrorism measures. Brigitte, previously suspected by French authorities of terrorism related involvement leading up to the 1998 Rugby World Cup, obtained a tourist visa to visit Australia in May 2003. Initial information was not however received by ASIO from the French authorities until 22 September, including that he reportedly participated in terrorist training, a communication that was treated as routine. Some ten days passed and the French received no reply to their first communication. On Friday 3 October, the French authorities sent a second communication, indicating that Brigitte may have been in Australia in connection with terrorism related activity and that he was 'possibly dangerous'. 4 That communication was not acted upon by ASIO until Tuesday 7

\footnotetext{
${ }^{1}$ Attorney General Hon Philip Ruddock, 'Press Conference Announcing A Review of Migration Litigation and Answering Questions On Deportation Of French National', Transcript 27 October 2003 <http://www.ag.gov.au/www/ministerruddockhome.nsf/Web+Pages/D001D7DF29EB8> (19 November 2003).

${ }^{2}$ Minister for Foreign Affairs and Trade, Hon Alexander Downer, House of Representatives, Hansard, 4 November 2003, 21847.

${ }^{3}$ Brigitte's Guadelopean-based lawyer, Harry Durimel, interviewed by ABC Foreign Correspondent journalist Evan Williams in December 2003 for Four Corners, Transcript: <http://www.abc.net.au/4 corners/content/2004/20040209_brigitte/int_durimel.htm> (24 February 2004).

${ }^{4}$ See ABC Four Corners, 'Willie Brigitte' broadcast, 9 February 2004, Transcript:
} 
October, the relevant communications area being closed for the intervening Labour Day holiday weekend in the Australian Capital Territory. ${ }^{5}$

Brigitte was placed under immigration detention for breach of his visa conditions on 9 October 2003 and deported on 17 October $2003,{ }^{6}$ being subsequently detained by the French authorities. It was subsequently suggested that he would be released due to a lack of substantive evidence relating to terrorist activities. ${ }^{7}$ However, according to transcripts of an interrogation conducted by a French anti-terrorism magistrate, Brigitte has admitted presence at the Lashkar E. Tayiba complex near Lahore, Pakistan in 2001-2002. ${ }^{8}$ In November 2003, Lashkar E Tayiba was proscribed as a terrorist organisation in Australia, ${ }^{9}$ thus attracting the operation of provisions of the Criminal Code Act $(\mathrm{Cth})^{10}$ inserted by the Security Legislation Amendment (Terrorism) Act 2002 (Cth). ${ }^{11}$

<http://www.abc.net.au/4corners/content/2003/transcripts/s1040952.htm> (24 February 2004); Hon Philip Ruddock 'Search Warrants After Australia-France Terrorism Link' Media Release 26 October $2003<$ 〈http://www.ag.gov.au/agd/WWW/MinisterRuddockHome.nsf/Page/Media_Releases_2〉

(1 November 2004). See also House of Representatives, Hansard, 3 November 2003, 21727 (Hon Philip Ruddock) and Martin Chulov, 'Brigitte suspects: police thwarted' The Australian, 9 February 2004,1 .

${ }^{5}$ See also Senate Legal and Constitutional Legislation Committee Estimates, Hansard, 16 February 2004, 4-5 regarding the date and receipt of the first and second communications from the French authorities to ASIO.

${ }^{6}$ Ruddock, above n 4. See also House of Representatives, Hansard, 3 November 2003, 21727 (Hon Philip Ruddock).

7 See Orietta Guerrera 'PM defends role in terror suspect's extradition', The Age (Melbourne), 17 January 2004, 6; 'Brigitte release imminent for 'lack of evidence' ABC News On Line 16 January 2004 <http://www.abc.net.au/cgi-bin/common/printfriendly.pl?http://www.abc.net.au/news/newsitems/s10> (16 January 2004). Brigitte's Australian spouse, Melanie Brown, was also detained whilst in France seeking access to Brigitte: see Alain Acco and Martin Chulov, 'Brigitte's wife held in Paris', The Australian, 22 January 2004, 1; Freya Petersen, 'Lawyer relaxed as Brigitte's wife held', The Age (Melbourne), 23 January 2004, 7. Reports about the presentation by French counter-terrorism authorities during detention to Brown of a detailed case against Brigitte contradicted such claims: see Martin Chulov and Alain Acco, 'Brigitte's duped wife turns on him', The Australian, 28 January 2004, 1 and 'Brigitte's wife to leave him', The Age, 30 January 2004, 7.

${ }^{8}$ See 'Interrogation: Willy Brigitte', Edited transcript from the interrogations of Willie Brigitte by magistrate Jean-Louis Bruguiere, ABC Four Corners broadcast 9 February 2004

<http://www.abc.net.au/4corners/content/2004/20040209_brigitte/interrogation.htm>

(24 February 2004). See also transcript 'Willie Brigitte', Four Corners, above n 4 and transcript of interview with Harry Durimel, above n 3.

${ }^{9}$ Criminal Code Amendment (Hamas and Lashkar-E-Tayiba) Act 2003 (Cth). See further discussion under the subsequent heading 'Executive control: politicising a counter-terrorism response'.

${ }^{10}$ See Criminal Code Act 1995 (Cth) ss 102.2 to 102.8 .

${ }^{11}$ See Greg Carne, 'Terror and the ambit claim: Security Legislation Amendment (Terrorism) Act 2002 (Cth)' (2003) 14 Public Law Review 13, 13. 


\section{B A synopsis of the article}

This article commences with a brief examination of the political responses to the Brigitte incident and the institutional implications of such responses, arising from the executive assertion that based upon a comparison with French counter-terrorism laws, new ASIO detention and questioning powers require significant expansion. Such political responses evidence significant and alarming trends steadily eroding rule of law principles and will produce more narrowly based democratic institutions and practices, such risks being highlighted by various United Nations human rights bodies.

An analysis is then made of the ASIO detention and questioning powers, to provide a foundation for evaluating both the Attorney-General's claim arising from the Brigitte incident for enhanced power and in surveying some of the characteristics recent legislative reform, including the ASIO Legislation Amendment Act 2003 (Cth). It is submitted that the constant review, re-working and re-visiting of those powers reflects a more overt politicisation of counter-terrorism responses. Similarly, internal executive review of the powers is considered to be at the expense of more measured, deliberative and democratic review, providing an opportunity, through departmental review, for reinstating draconian characteristics of the original bill, which are considered. In general, there is an increasing executive dimension over the complexion of the legislation, reflecting a more restricted and contingent quality of democracy. Executive features of the legislation and its surrounding issues, as perceived by the former and present Attorneys-General, are examined as providing insights into the ongoing reform issues given new impetus by the Brigitte incident.

The article then argues, in the context of issues directly arising from and relevant to the Brigitte incident, that the claims for expanded detention and questioning powers have been improperly presented and are unsubstantiated: the existing unprecedented detention and questioning powers being criticised out of context; inappropriate inter-jurisdictional comparisons being made for the powers; favourable consideration given French terrorism laws, but omitting systemic human rights abuses arising from those powers established by United Nations treaty bodies, the European Court of Human Rights and Amnesty International; confusion over criminal law versus intelligence gathering models; a reliance upon a highly problematic rights balancing model in reconciling security and liberty, as well as contradictions in an expansion of the powers with preferred and publicly articulated accountability models.

The article concludes, through highlighting several consequences from the preceding arguments, that there is neither a rational nor substantiated case for the claim to loosen constraints on already unprecedented detention and questioning powers. 


\section{Background and context: the political response to the Brigitte incident}

An apparent failure of intelligence exchange and communication between France and Australia, resulting in a person with suspected terrorist links being admitted to Australia, carries considerable legal significance and a potential for significant political damage to the government. The Attorney General has sought to politically capitalise upon the incident, emphasising the effectiveness of Australia's cooperative counter-terrorism arrangements. The Attorney General also hinted that based upon a comparison with French anti-terrorism laws, ASIO requires a significant expansion of its recently acquired detention and questioning powers. ${ }^{12}$ This comparison has been used to partly explain the deportation of Brigitte on the grounds of the supposed inadequacy of the ASIO detention and questioning regime. ${ }^{13}$ This is a remarkable claim given that these new powers were not applied to Brigitte $^{14}$ and the fact that the powers have twice been significantly expanded. ${ }^{15}$

The apparent attempt to turn the political negative ${ }^{16}$ of Brigitte's presence in Australia on a tourist visa for several months and the serious attendant delays in acting on French intelligence communications, into a positive by claiming that significantly and recently enhanced intelligence agency powers require further substantial expansion, highlights trends compromising and transforming democratic governance and the rule of law. Australian counter-terrorism legislative responses, of which the Brigitte incident is an illustrative example, have steadily eroded rule of law principles - accountability of institutions, due process, separation of power, scrutiny of authority, constraints on the exercise of discretions and a cogent justifi-

\footnotetext{
12 'Intelligence delay has Ruddock asking questions', ABC Lateline broadcast, 27 October 2003, Tran script: <http:www.abc.net.au/lateline/content/2003/s976417.htm> (19 November 2003); 'Interview: Philip Ruddock' Sunday program broadcast 2 November 2003 Transcript

<http://sunday.ninemsn.com.au/sunday/includes/fetchcontent.asp?purl=/sunday/politica> (2 November 2003) and 'New anti-terrorism laws too cumbersome: Ruddock' ABC News Online 10 November 2003 <http://www.abc.net.au/cgi-bin/common/printfriendly.pl?http://www.abc.net.au/news/n> (21 November 2003).

${ }^{13}$ See Ruddock, above n 1 and 'Item: Attorney-General Philip Ruddock Confirms ASIO Has Used Its New Powers To Interrogate Australian Associates Of French Terror Suspect Willie Brigitte', Transcript 10 December 2003

<http://www.ag.gov.au/www/MinisterRuddockHome.nsf/Web+Pages/446C96F9F842> (11 December 2003).

${ }^{14}$ See Senate, Hansard, 2 December 2003, 18252-18253 (Senator Hon Chris Ellison); Senate, Hansard, 2 December 2003, 18270 and 3 December 2003, 18359 (Senator Brian Greig); Senate, Hansard, 4 December 2003, 18788 (Senator Hon Chris Ellison). See also Ruddock, above n 12; and Ruddock 'Interview: Philip Ruddock', above n 12.

${ }^{15}$ Firstly, in the scope of the applicable powers in the bill compared to what was mooted in the time leading up to the introduction of the bill and secondly, in the Government's 'compromise', extending permissible detention on a single warrant from 48 hours to 168 hours: see the discussion in the sections of this article 'Prospective change: liberalising the criteria for obtaining detention and questioning warrants' and 'ASIO Questioning and Detention Powers: A Synopsis', which follows. See also A-G's Press Releases "New Counter-Terrorism Measures" 2 October 2001

<http://www.ag.gov.au/agd/WWW/attorneygeneralHome.nsf/Page/Media_Releases_200> (1 November 2004) and 'Compromise For The Sake Of National Security', 11 June 2003

<http://www.ag.gov.au/www/attorneygeneralhome.nsf/Web+Pages/D7604110820D9D> (12 June 2003).

${ }^{16}$ See especially House of Representatives, Hansard, 5 November 2003, 21967 (Kevin Rudd).
} 
cation for intrusive powers ${ }^{17}$ - and such erosion is reflected both in the attitudes of the legislative proponents and in the legislation itself. As one commentator has pointedly observed:

The core principles which distinguish liberal democratic regimes from authoritarian ones - 'the rule of law; openness and accountability of government; and the maintenance of a bond of trust and confidence between citizens and government that results from an electorate that is informed about public affairs'- have increasingly been put under strain by the continuing expansion of security operations according to a broad mandate of 'counter-terrorism'. ${ }^{18}$

This continued expansion is an identifiable trend in Australian reforms and is strongly reflected in the political response to the Brigitte incident.

\section{Background and context: some institutional implica- tions of the executive response to Brigitte incident}

The Attorney-General's response to the Brigitte incident is distinctive for its overt political approach in shifting responsibility for, and in seeking remediation of a national security administrative and policy failure, through advocating a further expansion of counter-terrorism detention and interrogative powers. In contrast, maintaining liberal democratic values, the anathema of international terrorism, in the absence of a bill of rights, ${ }^{19}$ presumes political restraint and reasonableness in the exercise of legislative and executive power and an overriding commitment to the characteristics of free and open societies wherever immediate party political advantages arise. Otherwise, incremental erosions of civil and political rights, brokered over potentially decades in countering terrorism, will ultimately destroy from within the same defining values, institutions and practices of democratic governance. As state authority becomes more omnipresent, a shift will occur in the nature of the Australian polity.

The risk of this type of development has been identified by various United Nations institutions. The High Commissioner for Human Rights, ${ }^{20}$ the Commission on

\footnotetext{
${ }^{17}$ See also Jenny Hocking, Terror Laws, ASIO, Counter-Terrorism and The Threat to Democracy (2004), 247.

${ }^{18}$ Hocking, above n 17, 246.

${ }^{19}$ Refer to the discussions on this point by George Williams: George Williams, 'Australian Values and the War Against Terrorism' (2003) 26 University Of New South Law Journal 191, 197 and George Williams, The Case For An Australian Bill Of Rights: Freedom In The War On Terror (2004)

${ }^{20}$ See, as examples, the work of the United Nations High Commissioner for Human Rights: Report of the United Nations High Commissioner for Human Rights And Follow-Up To The World Conference On Human Right,s Human Rights: A Uniting Framework, 27 February 2002 UN Document E/CN.4/2002/18 especially 3-7, 9-12, 15; 'Action Against Terrorism Must Not Undermine Human Rights, Say High Commissioner For Human Rights', Council of Europe and OSCE' UN Press Release 29 November 2001

<http://www.unchr.ch/huricane/huricane.nsf/view01/AD7D80AC9CB53F23C1256B1> (10 June 2002) including Joint Statement by UN High Commissioner for Human Rights, Secretary General of the
} 
Human Rights ${ }^{21}$ and the Sub-Commission on the Promotion and Protection of Human Rights $^{22}$ of the UN Economic and Social Council, the Secretary-General, ${ }^{23}$ the Secretary-General's Policy Working Group on the United Nations and Terrorism ${ }^{24}$ the CERD Committee, ${ }^{25}$ the CAT Committee ${ }^{26}$ and the UN General Assembly $^{27}$ have responded to the this concern. A constant theme of these UN human rights bodies has been the need to produce a more holistic appraisal of the concept of security, so that human rights values are fully integrated with responses to terrorism. Such considerations are of increased significance in the Australian context, as the lack of a bill of rights deprives policy and legislative development of a formal legal mechanism to test the reasonableness, proportionality and necessity of serial counter-terrorism reforms.

Whilst Australia would traditionally be described as having strong liberaldemocratic institutions, practices and traditions, amendments to the ASIO Act 1979 (Cth) in $1999,{ }^{28} 2002^{29}$ and $2003^{30}$ have created significant enhancements of executive power of a degree and nature detrimentally impacting upon civil and political rights. The res gestae of the Brigitte incident and the Executive response to it suggest that such movement is likely to intensify and consolidate. In the present environment of serial claims for enhancing counter-terrorism powers, new and mooted

Council of Europe and Director of the OSCE Office for Democratic Institutions and Human Rights 29 November 2001

< <http://www.unhchr.ch/huricane/huricane.nsf/(Symbol)/OHCHR.STM.01.66.En?Open>

(10 June 2002); and 'Post 11 September Efforts Should Lead To More Human Security, Not Rollback In

Civil Liberties, UN Rights Chief Says' (Fifth Commonwealth Lecture) UN Press Release 6 June 2002 <http://www.unhchr.ch/huricane/huricane.nsf/view01/C321FAFF25F1424AC1256BD0>

(10 June 2002)

${ }^{21}$ Commission on Human Rights resolution 2001/37 23 April 2001, Human Rights and Terrorism <ttp://www.unhchr.ch/Huridocda/Huridoca.nsf/TestFrame/d2ece80ebc3b8f74c1256a40> (3 May 2003).

Commission on Human Rights resolution 2002/35 22 April 2002, Human Rights and Terrorism <http://www.unHchr.ch/Huridocda/Huridoca.nsf/TestFrame/bab46260c4a1131bc1256ba> (3 May 2003).

${ }^{22}$ Terrorism and Human Rights: Second progress report prepared by Ms Kalliopi K. Koufa, Special Rapporteur UN Document e/CN.4/Sub.2/2002/35 17 July 2002.

${ }^{23}$ Report of the Secretary-General on implementation of General Assembly resolution 57/219 UN Document <E/CN.4/2003/120 20 March 2003

<http://www.unhchr.ch/Huridocda/Huridoca.nsf/TestFrame/90504a8bb2031985c1256cf > (3 May 2003)

${ }^{24}$ Report of the Policy Working Group on the United Nations and Terrorism UN Document A/57/273 S/2002/875

${ }^{25}$ CERD Committee Statement on racial discrimination and measures to combat terrorism UN Document A/57/18 (Chapter XI)(C)(Statement)

<http://www.unhchr.ch/tbs/doc.nsf/385c2add1632f4a8c12565a9004dc311/44f56d54190> (5 May 2003)

${ }^{26}$ Statement of the Committee Against Torture UN Document CAT/C/XXVII/Misc.7, 22 November 2001

${ }^{27}$ General Assembly Resolution 57/219, Protection of human rights and fundamental freedoms while countering terrorism, 27 February 2003 UN Document A/RES/57/219; General Assembly Resolution 56/160 Human Rights and terrorism 13 February 2002 UN Document A/RES/56/160.

${ }^{28}$ The ASIO Amendment Act 1999 (Cth) expanded a range of technical and other intelligence gathering techniques.

${ }^{29}$ ASIO Legislation (Terrorism) Amendment Act 2002 (Cth). This Act is discussed under the heading 'ASIO Questioning and Detention Powers: A Synopsis', below.

${ }^{30}$ ASIO Legislation Amendment Act 2003 (Cth). This Act is discussed under the heading 'Recent and Prospective Executive Claims for Enhanced Power: ASIO Legislation Amendment Act 2003 (Cth)', below. 
legislative reforms could exponentially erode various institutions and practices of Australian democracy. ${ }^{31}$

The assertiveness of executive authority, as evidenced in the Brigitte incident, is more readily identifiable with narrower, restrictive-elite models of democracy driving policy and legislative development. Such characteristics are reflected in and reinforced by the ASIO Legislation Amendment Act 2003 (Cth). ${ }^{32}$ The restrictiveelite model of democracy ${ }^{33}$ provides for a contracted participatory function for the people, limited to voting and discussion, ${ }^{34}$ to ensure the proper operation of electoral requirements. ${ }^{35}$ Political initiative and activity is to be generated by those seeking or holding elected office. ${ }^{36}$ Consistent with the competition of politicians for the limited role of citizens in securing their vote, those representatives are free to engage in political action of their own and are not answerable to instruction from, or obligation towards, enfranchised citizens. ${ }^{37}$ Such protection as exists against arbitrary rule is largely limited to the capacity to periodically remove offending politicians at elections. ${ }^{38}$

Features of this narrow model of democracy and its assumptions about the relations between the citizen and the state strongly resonate in the conferral of detention and questioning powers and in the executive claims from the Brigitte incident for further expansion of those powers. Such features include the method of a departmental review by the Attorney-General's department of existing powers ${ }^{39}$ in place of the public forums of a Parliamentary Committee or independent inquiry; constant Executive inspired reform for political rather than practical policy needs; and ex-

\footnotetext{
${ }^{31}$ The context surrounding the reforms is important, particularly the conflation of intelligence gathering and criminal investigation: see Jenny Hocking, 'Counter-Terrorism and the Criminalisation of Politics: Australia's New Security Powers of Detention, Proscription and Control' (2003) 49 Australian Journal of Politics and History 355, 364-365; Hocking, above n 17, 233 and Simon Bronnitt, 'Constitutional Rhetoric v Criminal Justice Realities: Unbalanced Responses to Terrorism?' (2003) 14 Public Law Review 76, 79

${ }^{32}$ Especially the provisions which suppress primary and secondary communications of information relating to detention and questioning warrants, including media reporting: see the discussion under the heading 'Recent and Prospective Executive Claims For Enhanced Power: ASIO Legislation Amendment Act 2003 (Cth)', which follows.

${ }^{33}$ See Joseph Schumpeter, Capitalism, Socialism and Democracy (1943) 105.

${ }^{34}$ Carol Pateman, Participation and Democratic Theory (1970) 5, in this sense involving a retreat from the public domain and practices of active political citizenship.

${ }^{35}$ Glen Patmore, 'Making Sense of Representative Democracy and the Implied Freedom of Political Communication in the High Court of Australia' (1998) 7 Griffith Law Review 97, 105; Pateman, above $n$ 34,5 .

${ }^{36}$ Pateman, above n 34,5 .

${ }^{37}$ David Held, Models of Democracy (1987), 165; Patmore, above n 35, 106.

${ }^{38}$ Jeremy Kirk, 'Constitutional Implications from Representative Democracy' (1995) 23 Federal Law Review 37, 47.

${ }^{39}$ The departmental review is discussed in more detail under the heading 'Executive control: revisiting or reworking an earlier legislative ambit claim?', which follows. The 2004 Parliamentary session has included a significant number of terrorism related legislative reforms: see Criminal Code Amendment (Terrorist Organisations) Act 2004 (Cth); Anti-Terrorism Act 2004 (Cth); Anti-Terrorism Act (No 2) 2004 (Cth); Anti-Terrorism Act (No 3) 2004 (Cth); National Security Information (Criminal Proceedings) Bill 2004 (Cth) and National Security Information (Criminal Proceedings)(Consequential Amendments) Bill 2004 (Cth)
} 
pressed executive dissatisfaction with negotiated Parliamentary outcomes in counter-terrorism legislation. Such restrictive-elite democratic model assumptions stand in marked contrast to the characteristics identifiable with broader democratic models, commonly identified as the protective, ${ }^{40}$ developmental $^{41}$, participatory $^{42}$ and pluralist ${ }^{43}$ models of democracy.

Distinctive and alarming political usages of national security reform may therefore be identified from the Brigitte incident. To fully comprehend such developments, discussion now turns to the legislative context from which they have emerged, namely the ASIO Legislation Amendment (Terrorism) Act 2003 (Cth) detention and questioning powers.

\footnotetext{
${ }^{40}$ A model intended to provide structures, practices and institutions controlling those possessing political power over those subject to that power. This control is achieved by the accountability of enfranchisement, regular elections by secret ballot, a separation of powers and freedoms of speech and public association: Patmore, above n 35, 97. The focus of the protective model of democracy is the protection of individual liberty: Kirk, above n 38, 46. The participation of the individual, whilst in the individual's interest, is necessarily instrumental to the greater good of the protection of governing institutions: Pateman, above n 34, 19-20; Held, above n 37, 67; Crawford Brough McPherson, The Life and Times of Liberal Democracy (1977) 35-37.

${ }^{41}$ The developmental model of democracy, accepting the principles of the protective model of democracy, further emphasises the moral and educational developmental benefits to the individual through participation in the political processes: Kirk, above $n$ 38, 46 and Patmore, above $n$ 35, 101-102. Political involvement is necessary not only for the protection of individual interests, but to create an informed, committed and developing citizenry and is essential to the 'highest and harmonious' expansion of individual capacities: Held, above n 37, 102. Developmental democracy is strongly associated with the writings of John Stuart Mill: Held, above n 37, 86.

${ }^{42}$ The participatory model of democracy derives from some of the rationales of developmental democracy, but goes beyond the quite restricted form of participation advocated by JS Mill: see Kirk, above $\mathrm{n}$ 38, 46 and Patmore, above n 35, 103. A participatory model of democracy encourages maximisation of individual opportunities to participate in political decisions, to develop the necessary qualities to enable citizens to assess the activities of representatives and hold them accountable: Patmore, above n 35, $102-$ 103. Participation expands beyond voting and discussion in representative government to include democratisation and politicisation of institutions in which individuals can play a significant role: Patmore, above n 35, 104. Involvement and contestation are significantly expanded, changing relationship between representatives and represented and the nature of representation itself.

${ }^{43}$ The pluralist model of democracy states that individual interests of the individual are best represented through membership of an interest group competing on political and policy terms with other groups to influence government. The political objectives of pluralism do not necessarily comprise the interests and values constituting the identity of the community as a whole: Jurgen Habermas 'Three Normative Models of Democracy' in Seyla Benhabib (ed), Democracy and Difference Contesting The Boundaries of The Political (1996) 25. Pluralism assumes basic norms and rules to regulate the contest of competing groups, including the role of the state as a regulator to protect group rights: Paul Hirst, Representative Democracy and Its Limits (1990), 16. Such a state protective capacity involves a legal order regulating the interaction of groups with lawmaking and enforcement capacity: Hirst, 17.
} 


\section{Asio Questioning ANd Detention Powers: A Synopsis}

\section{A The warrant detention and questioning powers}

In June 2003, after 18 months of protracted debate and significant modifications to the original bill following three parliamentary committee reports, ${ }^{44}$ the ASIO Legislation Amendment (Terrorism) Act 2003 (Cth) was enacted. It conferred upon ASIO a range of unprecedented powers in relation to the gathering of intelligence about, as distinct from the criminal investigation of, a range of separately legislated terrorism offences, ${ }^{45}$ enacted following the September 112001 attacks in the United States. A synopsis of these special powers, directed towards the gathering of intelligence and providing for incommunicado detention of non-suspects and suspects alike, will be useful in assessing the claim of the Attorney-General that these powers require expansion.

These warrant procedures, the liberalisation of which has now been raised by the Attorney-General, have previously been promoted as constituting considerable safeguards. ${ }^{46}$ Existing procedures for obtaining questioning and detention warrants

\footnotetext{
${ }^{44}$ Parliament of the Commonwealth of Australia, An Advisory Report on the Australian Security Intelligence Organisation Legislation Amendment (Terrorism) Bill 2002, Parliamentary Joint Committee on ASIO, ASIS and DSD Canberra, May 2002; Parliament of the Commonwealth of Australia, Provisions of the Australian Security Intelligence Organisation Legislation Amendment (Terrorism) Bill 2002, Senate Legal and Constitutional Legislation Committee, June 2002; Parliament of the Commonwealth of Australia, Australian Security Intelligence Organisation Legislation Amendment (Terrorism) Bill 2002 and Related Matters, Senate Legal and Constitutional References Committee, December 2002.

45 'Terrorism offence' is defined as meaning an offence against Division 72 or Part 5.3 of the Commonwealth Criminal Code: see ASIO Act 1979 (Cth) s 4. The Security Legislation Amendment (Terrorism) Act 2002 (Cth) inserted a new Part 5.3 into the Commonwealth Criminal Code, comprehensively defining 'terrorist act' as based on an act or threat of action where the action or threat of action is made with the intention of advancing a political, or a religious or ideological cause. The relevant action must be one which (a) causes serious harm that is physical harm to a person; (b) causes serious damage to property; (ba) causes a person's death; (c) endangers a person's life, other than the life of the person taking the action; (d) creates a serious risk to the health or safety of the public or a section of the public; or (e) seriously interferes with, seriously disrupts, or destroys an electronic system. Using that definition, an extensive array of individual and organisational offences is created: see Commonwealth Criminal Code ss 101.1-101.6 and Commonwealth Criminal Code ss102.2-102.7 for offences arising from the power to proscribe organisations as terrorist organisations. See also Carne, above n 11, 14-15. A further Criminal Code (Cth) s 102.8 offence of associating with a terrorist organisation was inserted by the AntiTerrorism Act (No.2) 2004 (Cth).

${ }^{46}$ The former Attorney-General, the Hon Daryl Williams AM QC MP referred to the warrant request and issuing process as a 'strict safeguard': see Attorney-General's Press Release 21 March 2002 'ASIO Legislation Amendment Bill Introduced'

<http://www.ag.gov.au/www/attorneygeneralHome.nsf/Web+Pages/DB85B938C9D66B4CCA256B> (12 January 2004) and House of Representatives, Hansard, 20 March 2003 13172. It is this same 'strict safeguard' that the present Attorney-General has signalled a need to significantly weaken. For a contrary view, see Sarah Pritchard, 'The Counter-Terrorism Bills' (2002) (Winter) Bar News: Journal of the NSW Bar Association 10, 15.
} 
involves different stages of approval with corresponding criteria. The Director General may seek the consent of the Attorney General to request the issue of a warrant under s.34D of the ASIO Act 1979 (Cth) in relation to a named person. ${ }^{47}$ The Attorney-General may, by writing, consent to the making of the request, if certain criteria are in fact satisfied, namely:

(a) that there are reasonable grounds for believing that issuing thewarrant to be requested will substantially assist the collection of intelligence that is important in relation to a terrorism offence; and

(b) that relying on other methods of collecting that intelligence would be ineffective; and

(c) if the warrant to be requested is to authorise the person to be taken into custody immediately, brought before a prescribed authority immediately for questioning and detained - that there are reasonable grounds for believing that if the person is not immediately taken into custody and detained, the person:

(i) may alert a person involved in a terrorism offence that the offence is being investigated; or

(ii) may not appear before the prescribed authority; or

(iii) may destroy, damage or alter a record or thing the person may be requested in accordance with the warrant to produce. ${ }^{48}$

Once the Attorney-General's consent to the making of the request for a warrant has been obtained in accordance with s 34C(4) of the ASIO Act 1979 (Cth), the issuing authority ${ }^{49}$ may issue a warrant if satisfied that there are reasonable grounds for believing that the warrant will substantially assist the collection of intelligence that is important in relation to a terrorism offence. ${ }^{50}$ If the issuing authority then issues the warrant it must be in the same terms as the draft warrant forming part of the request. ${ }^{51}$ In the case of a questioning only warrant, it must require the named person to appear before a prescribed authority ${ }^{52}$ for questioning under the warrant

\footnotetext{
${ }^{47}$ ASIO Act 1979 (Cth), s 34C, including requirements for the draft request: see s 34C (2).

${ }^{48}$ ASIO Act 1979 (Cth) s 34C (3)(a) (b) and (c). The Attorney General must also, under s 34C (3)(ba) be satisfied that a range of adopting acts (listed under s 34C (3A)) relating to a written statement of procedures (the protocol) have been completed. See also 'ASIO Protocol To Guide Warrant Process', Attorney General's News Release, 12 August 2003

<http://www.ag.gov.au/agd/WWW/attorneygeneralHome.nsf/Page/Media_Releases_200> (1 November 2004) and Parliament of Australia Australian Security Intelligence Organisation Protocol Tabled Paper 319 of 2003 (2003). S 34C (3B) of the Act also requires that the Attorney General must ensure that a warrant to be requested for custody and detention permits the detainee (subject to s.34 TA) to contact a lawyer of the detainee's choice after the detainee has been brought before a prescribed authority for questioning.

${ }^{49}$ ASIO Act 1979 (Cth) s 34AB enables the Attorney General to appoint as an issuing authority a consenting Federal magistrate or judge or a consenting person in a specified class declared by regulations to be an issuing authority.

${ }^{50}$ ASIO Act 1979 (Cth) s 34D(1)(b).

${ }^{51}$ ASIO Act 1979 (Cth) s 34D(2).

${ }^{52}$ A prescribed authority is a consenting person appointed by writing by the Minister who (1) has served as a judge in one or more of the superior courts for a period of 5 years and no longer holds a commission
} 
immediately after the person is notified of the issue of the warrant, or at a time specified in the warrant. ${ }^{53}$ In the case of a detention and questioning warrant, it must authorise the named person to be taken into custody immediately by a police officer, brought before a prescribed authority immediately for questioning under the warrant and detained under arrangements made by a police officer for the questioning period. ${ }^{54}$

Both forms of warrants are governed by section 34HB of the ASIO Act 1979 (Cth) providing for a regime of a maximum of 24 hours of questioning ${ }^{55}$ in three eight hour blocks of questioning in the presence of the prescribed authority. After each cumulation of eight hours of questioning, the prescribed authority, on application of a person exercising authority under the warrant, may only permit the questioning to continue if satisfied that:

(a) there are reasonable grounds for believing that permitting the continuation will substantially assist the collection of intelligence that is important in relation to a terrorism offence; and

(b) persons exercising authority under the warrant conducted the questioning of the person properly and without delay in the period mentioned in that subsection ${ }^{56}$

Section $34 \mathrm{HC}$ requires that a person cannot be detained under a warrant for a continuous period of more than 168 hours, although a capacity exists to obtain second and subsequent warrants on not especially onerous additional grounds. ${ }^{57}$ The proposal of the Law Council of Australia that a further five requirements ${ }^{58}$ need be satisfied before a second or subsequent warrant be approved was not accepted by the Parliament, so that the legislation 'will subject some of our fellow citizens to both interrogation and administrative detention for long and repeated periods'.

as a judge of a superior court or (2) if satisfied that there are an insufficient number of retired judges to act as prescribed authorities, appoint a person who is currently serving as a judge in a State or Territory Supreme Court or District Court (or an equivalent) and has done so for a period of at least 5 years or (3) if satisfied that there are an insufficient number of retired judges or currently serving State or Territory judges to act as prescribed authorities, appoint an AAT President or Deputy President who is enrolled as a legal practitioner of a federal court or the Supreme Court of a State or Territory and has been enrolled for at least 5 years: ASIO Act 1979 (Cth) s 34B (1) to (3).

${ }^{53}$ ASIO Act 1979 (Cth) s 34C (3)(a) (b) and (c).

${ }^{54}$ ASIO Act 1979 (Cth) s 34D (2) (b) (i).

${ }^{55}$ ASIO Act 1979 (Cth) s 34HB (6) states that persons exercising authority under a s.34 D warrant must not question a person under the warrant if the person has been questioned under the warrant for a total of 24 hours.

${ }^{56}$ Section $34 \mathrm{HB}$ (4) (a) and (b) of the ASIO Act 1979 (Cth).

${ }^{57}$ Aside from the s 34D (1)(b) requirement, the issuing authority must take account of the requirements of the person already having been detained in connection with one or more warrants: ASIO Act 1979 (Cth) s.34D (1A) (a), (b)(i) and (ii).

${ }^{58}$ The five additional requirements are listed in Duncan Kerr, 'Australia's legislative response to Terrorism', Paper delivered to the Criminal Bar Association of Victoria, 26 August 2003, 5.

${ }^{59}$ Kerr, above n 58, 5 . 
Several other features of the detention and questioning regime importantly confirm its draconian scope. Detention is incommunicado, in the sense that the subject of the warrant, who may not be suspected of any terrorism offence but may simply be thought to have relevant information, can disappear from the community for one week. A close examination of the legislation confirms that during this time there is no enforceable right of a detainee to notify family members or employers of one's whereabouts. ${ }^{60}$ Such concessions to discretionary communication ${ }^{61}$ with the outside world are subject to a range of contingencies. ${ }^{62}$

A person appearing before a prescribed authority for questioning under a warrant has the right of silence ${ }^{63}$ and privilege against self-incrimination ${ }^{64}$ removed. Use immunity in criminal proceedings of this information and records and things produced whilst before a prescribed authority for questioning under a warrant is provided, ${ }^{65}$ but not derivative use immunity.

Similarly, there are also significant restrictions on the role of lawyers during detention. $^{66}$ The incommunicado model of the detention is underlined in the fact that the legislative drafting fails to create an explicit right for a lawyer to be present at all times during detention and questioning, ${ }^{67}$ providing an ambiguity which may effectively exclude continuous legal representation and presence. ${ }^{8}$

Initially, limitations may be imposed upon the direction of the prescribed authority, relating to contact with a particular lawyer, on the basis of certain adverse circumstances relating to that lawyer would eventuate. ${ }^{69}$ A range of further limitations also exists. Contact between a person subject to the warrant and his or her legal adviser

\footnotetext{
${ }^{60}$ ASIO Act 1979 (Cth) s 34F (8).

${ }^{61}$ ASIO Act 1979 (Cth) s 34F (9).

${ }^{62}$ ASIO Act 1979 (Cth) s.34 D (2) (b) (ii) requires that a detention warrant issued by the issuing authority must, only in the most general and unspecific terms, 'permit the person to contact identified persons at specified times when the person is in custody or detention authorised by the warrant'. The requirement of 'specified times' is open to the specification of a contingency having the effect of preventing communication with the outside world. Similarly, s 34D (4) states that the 'warrant may identify someone whom the person is permitted to contact by reference to the fact that he or she... has a particular legal or familial relationship with the person...'. Whilst the person is before the prescribed authority for questioning under a warrant, the authority may give (d) a direction permitting the person to contact an identified person (including someone identified by reference to the fact that he or she has a particular legal or familial relationship with the person) or any person: s $34 \mathrm{~F}(1)(\mathrm{d})$. Such a direction by the prescribed authority must be consistent with the warrant or be approved in writing by the Minister: s 34F (2).

${ }^{63}$ ASIO Act 1979 (Cth) s 34G (3).

${ }^{64}$ ASIO Act 1979 (Cth) s 34G (6).

${ }^{65}$ ASIO Act 1979 (Cth) s.34G (9) (a) and (b).

${ }^{66}$ Section $34 \mathrm{C}$ (3B) requires that the drafting of the warrant for detention include provision to permit the detainee to contact a single lawyer of the person's choice.

${ }^{67}$ The legislation consistently refers to 'contact' with a lawyer: see s 34C (3B), 34D (4) and (4A), 34TA (1), (2) and (4), s 34 U (1) and (2). Significantly, s 34 TB (1) states 'To avoid doubt, a person before a prescribed authority for questioning under a warrant issued under section 34D may be questioned under the warrant in the absence of a lawyer of the person's choice'.

${ }^{68}$ Contrast the ambivalent situation relating to the presence of legal representation with the presence of the Inspector General of Intelligence and Security under the ASIO Act 1979 (Cth) s 34HAB and see also Hocking, above n 17, 229.

${ }^{69}$ ASIO Act 1979 (Cth) s 34TA (2) lists these circumstances.
} 
must be made in a way that can be monitored by a person exercising authority under the warrant. ${ }^{70} \mathrm{~A}$ legal adviser may not intervene in questioning of the person subject to the warrant or address the prescribed authority during questioning, except to request clarification of an ambiguous answer. ${ }^{71}$ Should the prescribed authority consider the legal adviser's conduct is unduly disrupting the questioning, the prescribed authority is able to direct removal of the legal adviser from the place where the questioning is occurring. ${ }^{72}$ Provisions which created general prohibitions of certain communications by legal advisers relating to the questioning or detention of the subject in the original version of the legislation have been repealed ${ }^{73}$ and replaced with new offences ${ }^{74}$ distinguishing between information disclosures before the expiry of a warrant ${ }^{75}$ and information disclosures in the two years after the expiry of the warrant, ${ }^{76}$ including the application of strict liability provisions to lawyers $^{77}$ in relation to specified elements of these offences. The application of strict liability provisions to lawyers is a practical and symbolic toughening of executive attitude to the operation of questioning and detention warrants.

The significance of the above provisions in their application to non-suspects is as much practical as it is symbolic and normative. The removal of the need to demonstrate culpability or involvement in terrorism offences as a precondition for the exercise of a warrant is of transformative significance in relations between the citizen and the state. ${ }^{78}$ It is a significant shift towards maximal state characteristics, particularly in the removal or diminution of procedural rights and protections. The breaching of the non-suspect threshold is likely to be exponential and facilitate further executive claims, such as those made by the Attorney-General, to erode democratic protections. The likelihood of such claims is heightened as the non-state terrorist threat is unpredictable, unknown, inevitable and indefinite. ${ }^{79}$

\footnotetext{
${ }^{70}$ ASIO Act 1979 (Cth) s $34 \mathrm{U}(2)$.

${ }^{71}$ ASIO Act 1979 (Cth) s $34 \mathrm{U}(4)$

${ }_{72}$ ASIO Act 1979 (Cth) s 34 U (5).

${ }^{73}$ See ASIO Legislation Amendment Act 2003 (Cth) s 8 repealing ASIO Act 1979 (Cth) subsections 34U (7), (8), (9), (10) and (11).

${ }^{74}$ A more detailed discussion of these provisions follows below under the sub-heading 'ASIO Legislation Amendment Act 2003 (Cth)'.

${ }_{75}^{75}$ See ASIO Act 1979 (Cth) s 34VAA (1).

${ }^{76}$ See ASIO Act 1979 (Cth) s 34VAA (2).

77 See ASIO Act 1979 (Cth) s 34VAA (3).

78 In that the entire population is now potentially subject to intelligence gathering and surveillance, with consequences for release from intelligence gathering detention: see Hocking, above n 17, 233. The slippage of language and labelling from persons who may reasonably be thought to have information in relation to terrorism offences, into the categories of terrorist suspects themselves, indicates this phenomenon. In this context, see the comments about terrorist suspects and terrorists: House of Representatives, Hansard, 24 June 2004, 30562 (Hon Philip Ruddock).

${ }^{79}$ See Hocking, above n 17, 233.
} 


\section{Recent and Prospective Executive Claims FOR ENHANCED POWER}

Such developments have fostered an environment where the Attorney General can argue that the Senate's amendment of the original bill for ASIO detention and questioning powers produced inferior legislation ${ }^{80}$ with the circumstances of the Brigitte deportation justifying various amendments to Part II, Divisions 2 and 3 of the ASIO Act 1979 (Cth), only passed by the Senate in June $2003 .^{81}$

\section{A ASIO Legislation Amendment Act 2003 (Cth)}

The process of enlarging executive power has proceeded apace. The ASIO Legislation Amendment Bill 2003 (Cth) was introduced into the Parliament on 27 November $2003^{82}$ and passed a mere eight days later on 5 December 2003 without amendment and without reference to a parliamentary committee. ${ }^{83}$ The bill made several significant changes far in excess of their misleading description as 'technical amendments' ${ }^{84}$ It clearly reflects the modus operandi of crisis and urgency in national security amendments cultivated by the Attorney General ${ }^{85}$ and government.

The amendments enable ASIO to question persons where 'an interpreter is present at any time while a person is questioned under a warrant issued under section $34 \mathrm{D}^{86}$ for a total of six eight hour blocks in a 168 hour detention. ${ }^{87}$ It further re-

\footnotetext{
${ }^{80}$ Philip Ruddock, 'The Commonwealth Response to September 11: The Rule of Law and National Security', Speech at Gilbert and Tobin Centre of Public Law - National Forum on the War on Terrorism and the Rule of Law, New South Wales Parliament House, 10 November 2003- describing the outcome as possibly 'third or fourth best':

<http://www.ag.gov.au/www/MinisterRuddockHome.nsf/Alldocs/RWPA8C31B13B5C> (17 November 2003).

See also House of Representatives, Hansard, 5 November 2003, 21973-21974, stating '... when you endeavour to put in place checks and balances, the checks can outweigh the balances. That is what I think can happen... Certain powers not being used because people formed the view that they could not be used with certainty - and that is clear from the advice that was given by ASIO's head to the Senate estimates committee' (Hon Philip Ruddock).

${ }^{81}$ The June 2003 amendments were made by the ASIO Legislation Amendment (Terrorism) Bill 2003 (Cth). The ASIO Act 1979 (Cth) was subsequently amended in December 2003 by the ASIO Legislation Amendment Act 2003 (Cth), which is discussed immediately below.

${ }^{82}$ See House of Representatives, Hansard, 27 November 2003, 22885.

${ }^{83}$ See Senate, Hansard, 4 December 2003, 18798.

${ }^{84}$ The "technical" description by the Opposition misstates the nature of the amendment. It appears intended to avoid a politically damaging but principled amendment of the provisions: see House of Representatives, Hansard, 2 December 2003, 23119 (Robert McClelland) and Senate, Hansard, 3 December 2003, 18354 (Senator Hon John Faulkner). See the criticisms of this 'technical' description by Senator Bob Brown: Senate, Hansard, 3 December 2003, 18357 and 18358 and Senate, Hansard, 4 December 2003, 18785 and 18789.

${ }^{85}$ This method will be the subject of further discussion below.

${ }^{86}$ See ASIO Act 1979 (Cth) s 34HB (8).

${ }^{87}$ See ASIO Act 1979 (Cth) s 34HB (9) to (12).
} 
quires the surrender of passports by a person subject to a warrant under s.34D 88 and creates an offence of leaving Australia without the permission of the Director General of ASIO after a person has been notified of the issue of a warrant under s.34D and before the end of period specified in the warrant during which the warrant is to be in force. ${ }^{89}$ The capacity of the prescribed authority to make an order authorising detention of a person during the course of a questioning only warrant is confirmed by the inclusion of s.34F (2A).

Extensive provisions also prohibit the disclosure of information relating to warrants and questioning both before the expiry of the warrant ${ }^{90}$ and in the two years after the expiry of the warrant. ${ }^{91}$ These disclosure offences include unauthorised primary and secondary disclosures of an extensive range of information. The effect of these provisions is to criminalise media reporting of material within the broad terms of the prohibitions, including reporting of the fact that a detention and questioning warrant has been issued in relation to a specific matter.

These provisions will dramatically curtail public accountability of the application and operation of the detention and questioning warrants which reporting would instigate, as well as chill potential publication where legal questions arise about the scope of the legislation's disclosure offences. Consequently, the Attorney General becomes the source of authorised disclosures of information on the operation of the warrants, able to control debate and accountability through selective release of information and invoking 'operational matters' as a rationalisation for declining further disclosure. Unsuccessful attempts were made to amend the bill to protect media disclosures of matters relating to detention and questioning warrants by applying a series of criteria, including that a public interest test be satisfied, and that national security not be threatened. ${ }^{92}$

The amendments are also likely to produce ripple effects in the strengthening of executive influence over detention and interrogative powers. The exclusion of

\footnotetext{
${ }^{88}$ See ASIO Act 1979 (Cth) s 34HB (9) to (12). The Anti-Terrorism Act (No 3) 2004 (Cth) extended the requirement to surrender Australian and foreign passports to earlier situations where the Director General of ASIO has merely sought the Attorney-General's consent to request the issue of a warrant for questioning and/or detention: See Anti-Terrorism Act (No 3) 2004 (Cth) Schedule 2, clause 34 JBA.

${ }^{89}$ See ASIO Act 1979 (Cth) s 34JD (1)(a) to (d) and (2).

${ }^{90}$ See ASIO Act 1979 (Cth) s 34VAA (1) (a) to (f). This involves disclosure of information where either of both (i) the information indicates the fact that the warrant has been issued or a fact relating to the content of the warrant or to the questioning or detention of a person in connection with the warrant or (ii) the information is operational information (providing the person disclosing that information has the information as a direct or indirect result of (i) the issue of the warrant or (ii) the doing of anything authorised by the warrant, by a direction given under subsection $34 \mathrm{~F}(1)$ in connection with the warrant or by another provision...in connection with the warrant, with the disclosure occurring before the end of the period for which the warrant is to be in force and the disclosure is not a permitted disclosure.

${ }^{91}$ See ASIO Act 1979 (Cth) s 34VAA (2) (a) to (f). These disclosures deal with operational information and the discloser has the information as a direct or indirect result of (i) the issue of the warrant or (ii) the doing of anything authorised by the warrant, by a direction given under subsection 34F (1) in connection with the warrant or by another provision of this Division in connection with the warrant...and the disclosure is not a permitted disclosure.

${ }^{92}$ See Senate, Hansard, 4 December 2003, 18791-18797.
} 
media reporting will curtail the availability of information and chill reporting of alleged improprieties and illegalities, removing a deterrent for abuse of power, diminishing literacy about case and policy issues, easing the passage of incremental diminutions of civil rights through serial amendments to the legislation, whilst depriving public and professional groups from important information necessary to make comprehensive submissions to the Joint Parliamentary Committee on Intelligence Services prior to expiry of the legislation under the sunset clause. ${ }^{93}$ This creation of an artificial situation, with the appearance of a successful, but untested, operation of the new intelligence gathering powers, will further constrain a critical and deliberative role for the Opposition and minor parties in additional reforms.

This suppression of media reporting under the ASIO Legislation Amendment Act 2003 (Cth) compounds two previously identified rule of law problems emerging with the conferral of detention and questioning powers on a secret organisation, whilst adding further secrecy dimensions. In the first instance, distinct accountability problems emerge when intelligence gathering is extended to incorporate policelike powers. As Williams observed:

If ASIO is to be granted coercive police powers, the Bill must subject the organisation to the same political and community scrutiny and controls that apply to any other police force. However, this is not compatible with the current intelligence gathering work of ASIO and its organisational structure (such as the secrecy applying to the identity of its employees). It would be difficult, if not impossible, for ASIO both to be sufficiently secretive to adequately fulfil its primary mission, as well as to be sufficiently open to scrutiny to exercise the powers set out in the ASIO bill. ${ }^{94}$

These additional layers of secrecy will suppress further already limited opportunities for scrutiny and accountability, particularly in relation to the formation of public and political opinion deriving from reporting, but also constraining the volume of publicly available information against which the Inspector General of Intelligence and Security, ${ }^{95}$ the Commonwealth Ombudsman ${ }^{96}$ and the Joint Parliamentary Committee on Intelligence Services ${ }^{97}$ can conduct their review functions.

\footnotetext{
${ }^{93}$ See ASIO Act 1979 (Cth) s 34 Y - Division 3 of Part III of the Act ceases to have effect 3 years after it commences. Intelligence Services Act 2001 (Cth) s 29(1)(bb) requires that the Joint Parliamentary Committee on Intelligence Services review by 22 January 2006 (i) Division 3 of Part III of the ASIO Act 1979 (Cth); and (ii) the amendments made by the ASIO Legislation Amendment (Terrorism) Act 2003, except item 24 of Schedule 1 to that Act (which included ASIO Act 1979 Division 3 of Part III).

${ }^{94}$ George Williams, 'One Year On: Australia's legal response to September 11' (2002) 27 Alternative Law Journal 212, 214-215. See also Hocking, above n 17, 224 and Joo Cheong Tham, "ASIO and the Rule of Law' (2002) 27 Alternative Law Journal 216, 217.

${ }^{95}$ See Inspector-General of Intelligence and Security Act 1986 (Cth) and ASIO Act 1979 (Cth) ss $34 \mathrm{HAB}, 34 \mathrm{HA}, 34 \mathrm{NC}$ and $34 \mathrm{Q}$.

${ }^{96}$ See Complaints (Australian Federal Police) Act 1981 (Cth) Part III and the ASIO Act 1979 (Cth) s $34 \mathrm{NC}$.

${ }^{97}$ See Intelligence Services Act 2001 (Cth) Part 4 ss 28 to 32 and Schedule 1, Part 1A, Part 1 and Part 2.
} 
Secondly, further layers of secrecy suppressing public reporting will enlarge the scope of ASIO discretionary powers ${ }^{98}$ under its charter, especially the circumstances in which warrants are sought ${ }^{99}$ and the conditions and duration of questioning and detention. ${ }^{100}$ Generalised media reporting may have appraised issues such as predictability and consistency in the use of discretions under the warrants and the effectiveness of legislative safeguards in controlling the operation of those discretions. Again, this suppression of information will be detrimental to the operation of the legislation's accountability mechanisms.

Further effects will flow in relation to access to judicial review. Strict liability provisions, ${ }^{101}$ creating a reverse onus of proof on the balance of probabilities, apply to the character and identity of information ${ }^{102}$ forming the basis of the information disclosure offence applicable to lawyers. ${ }^{103}$ The tightening of obligations on a detainee's lawyer not to disclose information obtained during ASIO interrogations will, in the context of the severe constraints on legal representation during interrogation, ${ }^{104}$ including regulations about communication by legal advisers of information relating to a person specified in a warrant ${ }^{105}$ and lawyers' access to information for proceedings relating to a warrant, ${ }^{106}$ further impede effective legal representation in accessing remedies in the courts in the case of individual detainees.

The amendments are also significant in their constitutional dimension. Questions as to the constitutionality of the suppression of information about and reporting of detention and questioning warrants were not raised in the Parliamentary debates, with the residual treatment in the legislation of the impact of the implied freedom of political communication ${ }^{107}$ repeating the casual attitude to the constitutionality of the original legislation. ${ }^{108}$ The tendency of the amendments to suppress information

\footnotetext{
${ }^{98}$ For a discussion of some issues relating to ASIO's discretionary powers, see Tham, above n 94, 217 218.

${ }^{99}$ Most significantly, in the formulation of the opinion that a detention warrant is required based on the elements of the ASIO Act 1979 (Cth) s 34 C (3)(c).

${ }^{100}$ In the application of the $A S I O$ Questioning Protocol made pursuant to subsection $34 \mathrm{C}$ (3A), setting basic standards in relation to the detention and questioning of a person pursuant to a warrant issued under the ASIO Act 1979 (Cth) s 34D and particularly in relation to s.34HB (3) requests to the prescribed authority by a person exercising authority under the warrant to permit the questioning to continue after intervals of 8 hours and 16 hours.

${ }^{101}$ See ASIO Act 1979 (Cth) s 34VAA (3) applying to paragraphs (1)(c) and (2)(c) of s 34VAA.

${ }_{102}$ ASIO Act 1979 (Cth) s 34VAA (1)(c) and 2(c).

${ }^{103}$ See ASIO Act 1979 (Cth) s 34VAA (3)(b)(i) to (iii). A 'lawyer' comprises those who have at any time been (i) present, as the subject's legal adviser, at the questioning of the subject under the warrant (ii) contacted for the purpose of the subject obtaining legal advice in connection with the warrant; or (iii) contacted for the purpose of the subject obtaining representation in legal proceedings seeking a remedy relating to the warrant or the treatment of the subject in connection with the warrant.

${ }^{104}$ See ASIO Act 1979 (Cth) ss 34TA, 34TB and 34U. The observations of Sydney lawyer Adam Houda representing clients believed to be the first interrogated under the provisions are mentioned in an article by Freya Petersen, 'Fears ASIO laws a threat to freedoms', Sydney Morning Herald, 1 December 2003.

${ }^{105}$ See ASIO Amendment Regulations 2003 (Cth) (No 1) Regulation 3A.

${ }^{106}$ See ASIO Amendment Regulations 2003 (Cth) (No 1) Regulation 3B.

${ }^{107}$ ASIO Legislation Amendment Bill 2003 (Cth) s 34VAA (12).

${ }^{108}$ See the discussion of this point under the sub-heading 'Executive review: revisiting or reworking an earlier legislative ambit claim?' which follows.
} 
and frustrate accountability may be seen as part of an interlocking array of prohibitions of disclosures of security related operations, capabilities, methods and sources $^{109}$ with espionage offences. ${ }^{110}$

\section{B Prospective change: liberalising the criteria for obtaining detention and questioning warrants}

To complement the suppression of reporting and information about detention and questioning warrants under the ASIO Legislation Amendment Act 2003 (Cth), the most significant change suggested by the Attorney General is an expansion of the grounds for the granting and duration of the warrants. From the Brigitte incident, the Attorney General has cultivated adverse comparisons between the detention and questioning powers under the ASIO Act 1979 (Cth) with those available to the French authorities, ${ }^{111}$ suggesting that the decision not to obtain an ASIO detention and questioning warrant for Brigitte was largely based on issues as to whether the necessary legal tests, under the existing warrant procedures, ${ }^{112}$ could be satisfied. ${ }^{113}$

The existing warrant process was previously seen as affording positive preliminary safeguards ${ }^{14}$ to the use of exceptional detention and questioning powers. ${ }^{115}$ Instead,

\footnotetext{
${ }^{109}$ See the array of espionage and similar activity offences concerning the security or defence of the Commonwealth under the Criminal Code Act 1995 (Cth) s 91.1. Under Criminal Code Act 1995 (Cth), s 90.1, 'security or defence of a country includes the operations, capabilities and technologies of, and methods and sources used by, the country's intelligence or security agencies'. In close similarity, 'operational information' in the ASIO Legislation Amendment Act 2003 (Cth) s 34VAA (5) comprises (a) information that ASIO has or had; (b) a source of information...that ASIO has or had and (c) an operational capability, method or plan of ASIO.

${ }^{110}$ See Michael Head, "Counter-Terrorism' Laws: A Threat to Political Freedom, Civil Liberties and Constitutional Rights' (2002) 26 Melbourne University Law Review 666, 674. Controversial measures to control the production and protect national security information in trials have been introduced to Parliament: see National Security Information (Criminal Proceedings) Bill 2004 (Cth) and the National Security Information (Criminal Proceedings)(Consequential Amendments) Bill 2004 (Cth) and refer to Australian Law Reform Commission, Keeping Secrets: The Protection of Classified and Security Sensitive Information, Report 98 (2004).

${ }^{111}$ With emphasis upon a capacity to detain terrorist suspects for up to three years while a case able to be prosecutable case is assembled, with the investigating judge merely having to make a determination that the detainee is able to assist with inquiries: see Ruddock, above n 1; Ruddock, 'Intelligence delay has Ruddock asking questions' above n 12; Ruddock, 'Interview: Philip Ruddock', above n 12; Tom Allard, 'ASIO needs new powers: Ruddock', Sydney Morning Herald, 3 November 2003; 'New antiterrorism laws too cumbersome: Ruddock', ABC Online 10 November 2003

<http:www.abc.net.au/cgi-bin/common/printfriendly.pl?http://www.abc.net.au/news/n> (21 November 2003); 'Interview transcript CNN Interview: Ruddock Discusses Guantanamo Bay Detainees and Counter-Terrorism Legislation' 11 November 2003

<http://www.ag.gov.au/www/ministerruddockhome:nsf/Web+Pages/481817735CFD5> (17 November 2003).

${ }^{112}$ See the discussion of the procedure for obtaining questioning and detention warrants under the heading 'ASIO Questioning and Detention Powers: A synopsis', above.

${ }^{113}$ See House of Representatives, Hansard, 3 November 2003 21727-21728, 21729 (Hon Philip Ruddock) and Ruddock, 'Interview: Philip Ruddock', above n 12.

${ }^{114}$ Refer to discussion under the sub-heading 'The warrant detention and questioning powers', above.

${ }^{115}$ Especially as they may be applied to persons entirely innocent of any involvement in terrorism offences, but whom may be thought to have information.
} 
the present Attorney General characterised, in a comparative context, ${ }^{116}$ the procedures as substantially obstructing intelligence work. ${ }^{117}$ This appraisal is even more extraordinary, firstly as the ASIO Act 1979 (Cth) detention and questioning powers were not used in the questioning of Brigitte prior to deportation and moreover, the questioning powers were used successfully in follow up investigations to the Brigitte incident. ${ }^{118}$ Moreover, the s.34D warrant request procedure complained of by the Attorney General is actually a clause drafted by the Government, which appeared in the original Australian Security Intelligence Organisation Amendment (Terrorism) Bill first introduced on 21 March 2002. ${ }^{119}$ The clause survived unchanged the many amendments made to the bill in the Senate. ${ }^{120}$ This unaltered clause was itself significantly broader in its scope than was contemplated in the months preceding introduction of the bill. ${ }^{121}$

This push for further liberalisation of warrant powers provides sharp insights into the evolving Australian relationship between civil rights and national security imperatives, with the former increasingly vulnerable to attrition as the supposed 'balance' in legislation is repeatedly contested and political opportunities are acted upon. This attrition is accelerated in that the constant focus is upon liberalising executive power relating to counter-terrorism measures, rather than a more effective utilisation of existing powers, as well as refining intelligence analysis, resources and communication. ${ }^{122}$ Whilst no cogent argument for liberalising already extraordinary warrant powers has been established, the exceptionality of such measures appears to have evaporated from the public debate. The Attorney General's complaint about an unnecessarily high approval threshold for the issue a warrant does

\footnotetext{
${ }^{116}$ However, and in complete contradiction, procedures have been positively cited elsewhere under the heading of 'Transparency and Accountability of ASIO Powers': Ruddock, above n 80.

${ }^{117}$ Some examples are the "very high level of supervision to the security agency when it undertakes to use those powers...quite significant limitations on the extent to which the powers can be used': Ruddock, above n 1; 'The powers that have been quite severely circumscribed by the Senate in terms of the way in which they are able to operate': Ruddock, 'Interview: Philip Ruddock' above n 12; '[S]ometimes there are trade offs. And we are in a position where we possibly have an outcome that is third or fourth best...There are issues associated with criteria under which a person may be questioned': Ruddock 'The Commonwealth Response to September 11: The Rule of Law and National Security' above n 80.

${ }^{118}$ See House of Representatives, Hansard, 5 November 2003, 21951 (Hon Simon Crean).

${ }^{119}$ See A-G's Press Release ‘ASIO Legislation Amendment Bill Introduced' 21 March 2002.

${ }^{120}$ See House of Representatives, Hansard, 3 November 2003, 21731 and 4 November 2003, 21854 (Robert McClelland).

${ }^{121}$ See A-G's Press Release 'New Counter-Terrorism Measures' 2 October 2001

<http://www.ag.gov.au/agd/WWW/attorneygeneralHome.nsf/Page/Media_Releases_200 > (1 November 2004) confining the proposed powers to 'politically motivated violence'. See also Report of Australia to the Counter-Terrorism Committee of the United Nations Security Council pursuant to paragraph 6 of Security Council resolution 1373 (2001) of 28 September 2001 (First Australian report to the UN Counter-Terrorism Committee), United Nations document S/2001/1247, 10; and James Renwick, 'The War Against Terrorism, National Security and the Constitution' (2002-2003) Bar News: Journal of the NSW Bar Association 42, 47, quoting Brett Walker SC.

${ }^{122}$ See Williams, above n 94, 215.
} 
suggest a politicised role in administering the present measures. ${ }^{123}$ A loosening of those warrant criteria would increase the risks of such politicisation.

\section{Executive review: revisiting or reworking an earlier legislative ambit claim?}

Following the Brigitte incident and consistent with a model of strong executive control and the marginalisation of broader democratic contributions, the AttorneyGeneral's department has been entrusted with an undisclosed departmental review of the legislation. ${ }^{124}$ An interest and opportunity therefore arises to revisit and repackage the most draconian characteristics of the original and subsequent versions of the ASIO Legislation (Terrorism) Bill 2002 (Cth), rejected by the Senate and heavily criticised in three Parliamentary Committee reports. ${ }^{125}$ A survey of the original bill's content will provide insights into why this present form of departmental review is unacceptable and how, in keeping with official comments from the Brigitte incident, will almost certainly find deficiencies with the existing legislation.

The original bill was a deeply flawed document undermining accepted rule of law procedural presumptions and standards of democratic accountability. ${ }^{126}$ It contained many drafting errors and ellipses and serially excised fundamental legal rights. ${ }^{127}$ The original bill nominated members of the Administrative Appeals Tribunal, lacking independence from the Executive and security of tenure, in the role of prescribed authorities. ${ }^{128}$ Indefinite detention was feasible, through a series of renewable 48 hour warrants ${ }^{129}$ and no right of access to legal representation existed. ${ }^{130}$ The bill did not require that a person taken into custody pursuant to a warrant be brought before a prescribed authority immediately for questioning. ${ }^{131}$

\footnotetext{
${ }^{123}$ See Michael Head, 'Counter-Terrorism Laws Threaten Fundamental Democratic Rights' (2002) 27 Alternative Law Journal 121, 122, asserting the highly political character of these measures. See also Daryl Williams, 'The Role of the Attorney-General' (2002) 13 Public Law Review, 252, 261-262.

${ }^{124}$ See Ruddock, above n 80; see also 'Interview: Philip Ruddock', above n 12 and Senate Legal and Constitutional Affairs Legislation Committee, Hansard, 3 November 2003, 145 (Senate Estimates). In contrast, the review in the United Kingdom of the Anti-Terrorism, Crime and Security Act 2001 (UK), by a nine member Privy Counsellor review committee was conducted over the extended period of 20 months: see Privy Counsellor Review Committee, Anti-terrorism, Crime and Security Act 2001 Review: Report (2003).

${ }^{125}$ See An Advisory Report on the Australian Security and Intelligence Organisation Legislation Amendment (Terrorism) Bill 2002, above n 44; Provisions of the Australian Security Intelligence Legislation Amendment (Terrorism) Bill 2002, above n 44; and Australian Security Intelligence Organisation Legislation Amendment (Terrorism) Bill 2002 and related matters, above $\mathrm{n} 44$.

${ }^{126}$ Legal representation was excluded. Other more extraordinary aspects of the bill are discussed immediately below.

${ }^{127}$ Hocking, above n 17, 215-217 surveys the most extreme provisions.

${ }^{128}$ ASIO Legislation Amendment (Terrorism) Bill 2002 Clauses 34B (1)(b)(i) to (iv) (original version of bill).

${ }^{129}$ Clauses 34C (5) (a) and (b) and 34D (2)(b)(i) (original version of bill).

${ }^{130}$ Clause 34D (4) (original version of bill).

${ }^{131}$ Evidenced by the wording of Clause 34D (2) (b) (i) of the original version of the bill 'authorise a specified person to be immediately taken into custody by a police officer, brought before a prescribed
} 
This omission would have allowed extended detention for the 28 day duration of the warrant. ${ }^{132}$ The treatment of the person during detention and questioning was left almost wholly unregulated, ${ }^{133}$ with no protocols or a statement of procedures governing the rights of detainees included within, or requiring implementation, by regulation or tabled document. No use immunity for information provided by detainees during questioning was provided under the bill, ${ }^{134}$ producing the remarkable situation where it may have been preferable for a detainee to refuse to provide the information sought during the intelligence gathering interrogation, and face a penalty of five years imprisonment, ${ }^{135}$ rather than face a heavier penalty upon conviction for a terrorism offence from information obtained during an act of selfincrimination.

Other alarming features characterised the bill. No offence or penalty was prescribed for officials who breached their obligations under the bill, most importantly in relation to the treatment and welfare of the detainee. ${ }^{136}$ Children of any age could be detained under the bill without the knowledge of their parents or guardian, ${ }^{137}$ and strip searches conducted on children as young as ten years old. ${ }^{138}$ The unremarked casualness which all of these measures encroached upon fundamental rights is perhaps best confirmed in the fact that no sunset clause existed in the bill, to underline its temporary and exceptional nature. ${ }^{139}$ Similarly, there was no provision for reporting the number of warrants issued for questioning and detention. ${ }^{140}$

In tabling the report of the bill, the Chair of the bi-partisan Joint Parliamentary Committee on ASIO, ASIS and DSD stated that 'The proposed legislation, in its

authority for questioning under the warrant and detained under arrangements made by a police officer for a specified period of not more than 48 hours starting when the person is brought before the authority'.

${ }^{132}$ See Clause 34D (6) (b) of the original version of the bill stated 'Also, the warrant must (b) specify the period during which the warrant is to be in force, which must not be more than 28 days'.

${ }^{33}$ Clause $34 \mathrm{~J}$ of the original bill provided the unenforceable statement '(2) The person must be treated with humanity and with respect for human dignity, and must not be subjected to cruel, inhuman or degrading treatment, by anyone exercising authority under the warrant or implementing or enforcing the direction.'

${ }^{134}$ Clause 34G (8) of the original bill stated that 'For the purposes of subsections (3) [information requested] and (6) [record or thing], the person may not fail: (a) to give information; or (b) to produce a record or thing; in accordance with a request made of the person in accordance with the warrant, on the ground that the information, or production of the record or thing, might tend to incriminate the person or make the person liable to a penalty.' Clause $34 \mathrm{G}$ (9) of the original bill created exceptions as to the admissibility in evidence against the person in criminal proceedings other than proceedings for an offence against this section or a terrorism offence.

${ }_{135}$ As prescribed by the clauses of the original bill: Clauses $34 \mathrm{G}(3)$ and $34 \mathrm{G}(6)$.

${ }^{136}$ That is, no penalty attached to a breach of Clause $34 \mathrm{~J}$, discussed above under the heading 'Executive review: revisiting or reworking an earlier legislative ambit claim?'

${ }^{137}$ In other words, the incommunicado form of detention was extended indiscriminately to adults and children: see Clause $34 \mathrm{~F}(8)$ of the original version of the bill.

${ }^{138}$ Clause $34 \mathrm{M}(1)(\mathrm{e})$ of the original version of the bill.

139 The inclusion of a sunset clause terminating the legislation three years from the date of its commencement was recommended in An Advisory Report on the Australian Security Intelligence Organisation Legislation Amendment (Terrorism) Bill 2002 above n 44, xvi (Recommendation 12).

${ }^{140}$ The inclusion by ASIO in its declassified Annual Report of the total number of warrants issued under the Act was recommended in An Advisory Report on the Australian Security Intelligence Organisation Legislation Amendment (Terrorism) Bill 2002 above n 44, xvi (Recommendation 11). 
original form, would undermine key legal rights and erode the civil liberties that make Australia a leading democracy'. ${ }^{141}$ A significant proportion of the criticism of the legislation by members of the Opposition related to the extraordinary and unchecked scope of the provisions of the original bill. ${ }^{142}$

Concerns about the nature of the ongoing internal review by the department are reinforced by earlier inadequacies in defending the constitutionality of the legislation. ${ }^{143}$ The approach by the department to the legislation before the Senate Legal and Constitutional References Committee appeared to minimise ventilation of its constitutionality, with the paucity and quality of the constitutional advice attracting the censure of the Committee Chair. ${ }^{144}$ It was observed in both a submission to the Committee $^{145}$ and by the Committee itself, ${ }^{146}$ that the legislation's constitutionality had been inadequately addressed by the department. ${ }^{147}$ The approach might be explained in risk appraisal terms, as litigation would need to test the legislation's constitutionality. ${ }^{148}$ Such a risk appraisal, giving insufficient attention to legality, is inimical to the rule of law.

The Attorney-General's departmental review of the detention and questioning powers signals an emerging trend to treat detailed parliamentary process as but a temporary impediment to government mandated executive outcomes, ${ }^{149}$ producing an increasingly restricted and contingent quality of democracy. These erosions of democratic principle are reinforced by the exclusion of public participation through

\footnotetext{
${ }^{141}$ See House of Representatives, Hansard, 5 June 2002 P 2846 (Hon David Jull, Chair of Joint Parliamentary Committee on ASIO, ASIS and DSD).

${ }^{142}$ See, for example statements by Senator John Faulkner Senate, Hansard, 17 June 200311566 and 11568 and Senate, Hansard, 18 June 200311677 and 11678; Senator Robert Ray Senate, Hansard, 25 June 2003, 12194 and Daryl Melham House of Representatives, Hansard, 12 December 2002, 10432 and 5 November 2003 21968-21969.

${ }^{143}$ The Attorney-General's department asserted that the Attorney General was satisfied that the bill was constitutional: Senate Legal and Constitutional References Committee, Hansard, 12 November 2002, $10-11$.

${ }^{144}$ See Senate Legal and Constitutional References Committee, Hansard, 12 November 2002, 19-20; 13 November 2002, 48 and 26 November 2002, 281. It was established that the only advice as to the constitutionality of the bill had been obtained from the Office of Parliamentary Counsel and the Australian Government Solicitor: Senate Legal and Constitutional References Committee, Hansard, 26 November 2002, 281.

145 Senate Legal and Constitutional References Committee, Hansard, 22 November 2002, 147, 154 (Dr Gavan Griffith QC)

${ }^{146}$ See Australian Security Intelligence Organisation Legislation Amendment (Terrorism) Bill 2002 and related matters, above n 44, 23 and Senate Legal and Constitutional References Committee, Hansard, 26 November 2002, 281

${ }^{147}$ This point might be reasonably deducted from an answer by the Attorney-General's Department to a question on notice in November 2002 from the Senate Legal and Constitutional References Committee: Attorney-General's Department Information and Security Law Division Senate Legal and Constitutional References Committee Answers to Questions on Notice - Attorney-General's Department, 1 (undated document).

${ }^{148}$ The lack of automaticity regarding unconstitutionality of the legislation and the need for the matter to go to court was explicitly mentioned in the evidence of the Attorney-General's Department: see Senate Legal and Constitutional References Committee, Hansard, 26 November 2002, 281.

${ }^{149}$ See Hocking, above n 17, 223.
} 
submissions to a parliamentary inquiry, ${ }^{150}$ a method more likely to test government claims, develop substantive safeguards and ventilate and deliberate expert submissions and public concerns.

\section{Executive control: original Ministerial conceptions}

With only four months and a change of Attorneys General ${ }^{151}$ between the passage of the exceptional detention and questioning provisions and the impetus of the Brigitte incident for further extension of powers and relaxation of their safeguards, identifying features of the executive response in the passage of the legislation also provides insight into the rationales of the ongoing reform claims.

Some distinctive executive characteristics emerge. Firstly, Attorney-General Williams portrayed the Government's approach as one of responsibility, determination in parliamentary negotiations, balance and reasonableness in advancing a workable bill to protect community safety ${ }^{152}$ and enable ASIO to 'get on with the job of protecting Australians and Australian interests'. ${ }^{153}$ In contrast, Senate and Opposition party amendments were criticised as being irresponsible, intransigent, unworkable and political point scoring exercises. ${ }^{154}$

${ }^{150}$ A further example of the distaste for such inquiries was apparent in relation to the Anti-Terrorism Bill (No.3) 2004 (Cth): see House of Representatives, Hansard, 24 June 2004, 30562. Similarly, the essential and democratic Parliamentary process of referral of the Anti-Terrorism Bill (No.2) 2004 (Cth) to the Senate Legal and Constitutional Legislation Committee for scrutiny was considered as 'delaying tactics...potentially adding months to the process': A-G's Press Release 8 July 2004 'Labor Delays Important Anti-Terrorism Legislation'

<http://www.ag.gov.au/www/MinisterRuddockHome.nsf/Web+Pages/4567DEEBC91726A4CA256E> (8 July 2004).

${ }^{151}$ The Hon Daryl Williams AM QC MP was Commonwealth Attorney General until 6 October 2003 and was succeeded by the Hon Philip Ruddock on 7 October 2003.

${ }^{152}$ See A-G's Press Releases 'Compromise For The Sake Of National Security' 11 June 2003 <http://www.ag.gov.au/www/attorneygeneralhome.nsf/Web+Pages/D7604110820D9D> (12 June 2003); 'ASIO Bill A Win For National Security' 17 June 2003

<http://www.ag.gov.au/attorneygeneralHome.nsf/Web+Pages/3D53E6D7167849> (18 June 2003)

'Stronger Tools For ASIO To Combat Terrorism' 26 June 2003

<http://www.ag.gov.au/www/attorneygeneralHome.nsf/Web+Pages/24D4E5BFA8A86> (29 June 2003) and 'Final passage Of ASIO Powers Legislation' 26 June 2003

<http://www.ag.gov.au/www/attorneygeneralHome.nsf/Web+Pages?E8A8FB88011F66> (29 June 2003).

${ }^{153}$ See A-G's Press Release 'ASIO Bill A Win For National Security' 17 June 2003

<http://www.ag.gov.au/www/attorneygeneralHome.nsf/Web+Pages/3D53E6D7167849> (18 June 2003).

${ }^{154}$ See A-G's Press Releases: 'Labor Refuses to Engage on Community Safety' 19 September 2002

<http://www.ag.gov.au/www/attorneygeneralHome.nsf/Web+Pages/47134D2C2037DF> (19 September 2002) 'ASIO Bill In Limbo' 17 October 2002

<http://www.ag.gov.au/www/attorneygeneralHome.nsf/Web+Pages/3A6A9D2ED0B12> (21 November 2003); 'Labor Chooses Delay Over Action On Terrorism' 21 October 2002

http://www.ag.gov.au/www/attorneygeneralHome.nsf/Web+Pages/52612A10FC0DD (21 November $2003)$; 'Labor Rejects Vital Counter-Terrorist Laws' 13 December 2002 http://

<152.91.15.12/www/attorneygeneralHome.nsf/Web+Pages/8E05313A4C92A04BC> (11 January 2003) and 'Australian Security Intelligence Organisation Legislation Amendment (Terrorism) Bill House Message' 13 December 2002

<http://www.ag.gov.au/www/attorneygeneralHome.nsf/Web+Pages/41A0B86D7B465> (21 November 2003). 
Further official comments supporting the bill were intended to persuade that incommunicado detention and questioning powers directed against non-suspects were truly exceptional. Attorney General Williams observed 'the bill is about intelligence gathering in extraordinary circumstances'; ${ }^{155}$ that it 'must be remembered that these warrants are a measure of last resort. It is anticipated that they will be used rarely and only in extreme circumstances' 156 and 'I hope that the powers under the legislation never have to be exercised'. ${ }^{157}$ Passage of the detention and questioning powers was seen as a triumph, producing effective and workable legislation, 'giving ASIO the powers it needs to do its job properly'. ${ }^{158}$ The regime of three eight hour blocks of questioning during a one week detention was a government sponsored 'compromise', ${ }^{159}$ significantly expanding the duration of detention under the original bill. ${ }^{160}$ It substantially enlarged the Opposition proposal, which sought to structure a legislative scheme around the somewhat contentious distinction between a questioning regime and a detention regime by proposing more limited blocks of questioning time. $^{161}$

\section{E Executive control: politicising a counter-terrorism response}

The present Attorney-General's comments from the Brigitte incident confirm a shift to an overt, professionalised politicisation of counter-terrorism issues, ${ }^{162}$ confusing partisan political interests and advantage with the security of the nation. These comments reflect an attitude that such issues are exclusively the remit of the executive, with non-government parliamentary or public contributions to the debate of

\footnotetext{
${ }^{155}$ A-G's Press Release 'Australian Security Intelligence Organisation Legislation Amendment (Terrorism) Bill House Message', 13 December 2002, above n 154.

${ }^{156}$ Senate, Hansard, 13 May 2003, 10584 (Senator Ian Campbell); House of Representatives Hansard 20 March 2003, 13172 (Hon Daryl Williams).

157 'ASIO laws finally passed', Sydney Morning Herald, 27 June 2003.

${ }^{158}$ A-G's Press Release 'ASIO Bill A Win For National Security' 17 June 2003.

<http://www.ag.gov.au/www/attorneygeneralHome.nsf/Web+Pages/3D53E6D7167849> (18 June 2003)

${ }^{159}$ See A-G's Press Release 'Compromise For The Sake of National Security' 11 June 2003

<http://www.ag.gov.au/www/attorneygeneralhome.nsf/Web+Pages/D7604110820D9D> (12 June 2003).

${ }^{160}$ From a 48 hour warrant, involving the detailed three stage process for renewal, to a single 168 hour warrant, with the capacity for further warrants providing certain, but not onerous conditions, were met: ASIO Act 1979 (Cth) s 34 D (1A).

${ }^{161}$ References to the proposed Opposition scheme of four hours of questioning, followed by two possible extensions of eight hours of questioning, applying to non-suspects are found in Senate, Hansard, 12 December 2002, 8153-8154 (Senator Hon John Faulkner); House of Representatives, Hansard, 12 December 2002, 10430-10431, 10533 and 10564 (Hon Simon Crean); House of Representatives, Hansard, 12 December 2002, 10435, 10569 (Hon Kim Beazley) and House of Representatives, Hansard, 12 December 2002, 10535 (Daryl Melham). See also Kim Beazley, 'ASIO Legislation Amendment (Terrorism) Bill 2002: A way forward' (Submission to Senate Legal and Constitutional References Committee), November 2002 and 'Table summarising the progress of the main issues in the ASIO Bill', Document released from office of Senator John Faulkner, 18 June 2003, identifying the key features of the Opposition model.

${ }^{162}$ A striking example of this is found in the Attorney-General's second reading speech of the AntiTerrorism Bill (No.3) 2004 (Cth), House of Representatives, Hansard, 24 June 2004, 30562
} 
marginal utility. ${ }^{163}$ Eschewing public debate and scrutiny by Parliamentary committees and encouraging the Opposition to accede to excessive, hastily conceived measures to avoid a political backlash, induces inferior legislative conditions for a coherent counter-terrorism response. It is a reinstatement of an ambit national security claim likely to be pursued by incremental measures. ${ }^{164}$ This elite, centralised executive control of national security response to terrorism is ultimately corrosive of the practices of participatory democracy and democratic institutions.

Several factors surrounding the Brigitte incident evidence this re-asserted executive control of national security issues. The rhetorical shift is amply demonstrated by the readiness to identify the legislative response to non-state terrorism with a war. ${ }^{165}$ Invoking the language of war $^{166}$ rationalises the sweeping aside of legal norms and niceties, ${ }^{167}$ justifying extreme measures as an instinctive legislative expression of state survival, ${ }^{168}$ creating an expectation of precedence of, and deference to, executive judgment. Its constitutional dimension invokes an expanded scope of the s.51 (vi) Defence power ${ }^{169}$ and in emergency situations, the prerogative aspect of the s.61 Executive power. ${ }^{170}$

Secondly, the Attorney General's advocacy of detention and questioning warrant criteria reform a mere four months after the conclusion of eighteen months of exhaustive debate, three parliamentary committee reports highly critical of the government's bill and extensive expert contribution is dismissive of the democratic

\footnotetext{
${ }^{163}$ See Hocking, above n 17, 213 and Senate, Hansard, 12 August 2004, 26081 (Senator Kerry Nettle quoting Joo-Cheong Tham's identification of a government 5 step technique of terrorism law change). See also Joo-Cheong Tham's comment on this technique in the Sydney Morning Herald (Sydney) webdiary 30 March 2004.

<http://www.smh.com.au/articles/2004/03/30/1080544481409.html?oneclick=true> (16 August 2004).

${ }^{164}$ This seriatum technique has already been foreshadowed and warned against in other terrorism law contexts: see Senate, Hansard, 7 November 2003, 16189 and 16826 (Senator Bob Brown) and 16825 (Senator Brian Greig).

${ }^{165}$ See Ruddock, above n 80. The identification of the terrorist threat as a war is also raised in 'Statement By The Attorney-General Philip Ruddock On National Security - Overseas Developments', 19 February 2004

〈http://www.ag.gov.au/www/MinisterRuddockHome.nsf/Web+Pages/5B8D376BE792B92CCA256>

(23 February 2004) attacking the Opposition for 'its incoherent and patchy approach to Australia's national security'.

166 The word 'war' is used on no fewer than six occasions under the heading 'Advent of Terrorism' in Ruddock, above $\mathrm{n} 80$. The words 'battle' and 'ally' are also included in this extract. See also A-G's Press Releases of 27 May 2004, 'Attorney-General Rejects Amnesty Criticism'

<http://www.ag.gov.au/www/ministerruddockhome.nsf/Web+Pages/16DB7F9B1AE0D267CA256E>

(27 May 2004) and 26 February 2004 'British Counter-Terrorism Options Examined'

<http:www.ag.gov.au/www/MinisterRuddockHome.nsf/Web+Pages/C2295DCF7EC17EDCA256E> (7) July 2004)

167 'When it comes to the war against terrorism, many of the subtleties usually associated with the fair and even application of the rule of law are not neatly applied': Ruddock, above $\mathrm{n} 80$.

${ }^{168}$ See Hocking, above $\mathrm{n} 31,359$.

${ }^{169}$ See Andrews v Howell (1941) 65 CLR 255, 278 (Dixon J); Stenhouse v Coleman (1944) 69 CLR 457,

471-472 (Dixon J) and Australian Communist Party $v$ Commonwealth (1951) 83 CLR 1, 253-255

(Fullagar J).

${ }^{170}$ See Farvey v Burvett (1916) 21 CLR 433, 452 (Isaacs J).
} 
contribution expended in that legislative process. ${ }^{171}$ Proposals other than genuine technical amendments will also pre-empt the important safeguard of a full bipartisan review of the operation, effectiveness and implications of the detention and questioning powers to be conducted by early 2006 by the Joint Parliamentary Committee on Intelligence Services, ${ }^{172}$ prior to the operation of the three year sunset clause in the legislation. ${ }^{173}$ Piecemeal amendments of the kind suggested, made in an anxiety laden security atmosphere, without proper consultative and deliberative processes, will fail to integrate a consideration of rights with the claims of security.

The underlying assumptions are that an Executive re-assessment of powers is unexceptional and that 'the new security environment' demands a suspension by the Senate of critical judgment, ${ }^{174}$ speed in the passage of legislation ${ }^{175}$ and the provision of cosmetic safeguards as concessions to rule of law concerns. Broad discretions and deference to Executive judgment in the legislation is considered essential, as such judgment must be readily exercisable to expand powers and contract protections in a fluid security environment. Legislative change is to be a constant, mediated through executive action largely freed from policy considerations of civil and political rights.

Thirdly, the executive characteristics prompted by the Brigitte incident are confirmed and highlighted in other developments which provide insights into the political environment of constant legislative revision in which the Attorney-General's reforms are being advanced. The clearest example is found in reform of the Criminal Code Act 1995 (Cth) provisions dealing with the proscription of organisations. ${ }^{176}$ The original bill ${ }^{177}$ vested a power in the Attorney General or delegate to

\footnotetext{
171 'Inevitably the final legislation was the product of considerable compromise and concession...I make no secret of the fact that I do not believe that the legislation as it stands is quite right...And we are in a position where possibly we have an outcome that is third or fourth best': Ruddock, above $\mathrm{n} 80$.

${ }^{172}$ Intelligence Services Act 2001 (Cth) s 29(1)(bb).

${ }^{173}$ ASIO Act 1979 (Cth) s 34Y.

${ }^{174}$ Much of the Attorney-General's criticism of the scope of the detention and questioning powers has been levelled against the Senate's amendments to the original bill. However, such criticisms need to be assessed in the context of the Government's strong conception of restrictive-elite democratic features on this issue, and its advocacy of Senate reform which would strip away the Senate's powers as an effective house of review: see Resolving Deadlocks: A Discussion Paper on Section 57 of the Australian Constitution (2003); Harry Evans, 'When reform adds up to a rubber stamp', The Age (Melbourne), 25 April 2002, 13 and Harry Evans, 'The Australian Parliament: Time for Reformation', Address to the National Press Club Canberra by Clerk of the Senate 24 April 2002.

${ }^{175}$ See advocacy for the speedy passage of the Criminal Code Amendment (Hamas and Lashkar-ETayyiba) Bill 2003 (Cth): House of Representatives, Hansard, 5 November 2003, 21974 (Hon Philip Ruddock) and a similar attitude about the role of Senate Committees scrutinising and reporting upon proscribed organisations legislation: House of Representatives, Hansard, 4 November 2003, 21844 (Hon Philip Ruddock). For a comparative discussion of the speed of passage of counter-terrorism legislation, see Dirk Haubrich, 'September 11, Anti-Terror laws and Civil Liberties: Britain, France and Germany Compared' (2003) Government and Opposition 3, 8-10.

${ }^{176}$ In the sense that the proscription of organisations forms the basis for a number of strict liability offences, being 'terrorism offences' for the purposes of the s.34D ASIO Act 1979 (Cth) warrant procedures.

${ }^{177}$ Security Legislation Amendment (Terrorism) Bill 2002 (Cth).
} 
proscribe organisations on four alternative grounds, ${ }^{178}$ such proscription forming the basis for applying a range of strict liability offences, carrying a maximum penalty of 25 years imprisonment. The legislation passed, ${ }^{179}$ however, allowed proscription only on narrower grounds. ${ }^{180}$ The significance of proscription is that it attracts a range of criminal offences, with substantial penalties, under the Commonwealth Criminal Code. ${ }^{181}$ Dissatisfied with this legislation, the Attorney-General vigorously pursued passage of the Criminal Code Amendment (Terrorist Organisations) Bill 2003 (Cth), providing for ministerial proscription by regulation of an organisation as a terrorist organisation. ${ }^{182}$ The primary reasons argued in support of ministerial proscription were executive in orientation - greater autonomy and flexibility, as well as asserting domestic sovereignty in contradistinction to reliance on action by the United Nations Security Council. ${ }^{183}$ The executive dominated approach to the proscription of organisations is reinforced by the ex post facto nature of the safe-

\footnotetext{
${ }^{178}$ Security Legislation Amendment (Terrorism) Bill 2002 (Cth) cl 102.2(1)(a)-(d). The most controversial of these grounds permitted proscription on the basis that the organisation has endangered, or is likely to endanger, the security or integrity of the Commonwealth or of another country: $\mathrm{Cl} 102.2$ (1)(d) of the Security Legislation Amendment (Terrorism) Bill 2002 (Cth).

${ }^{179}$ Security Legislation Amendment (Terrorism) Act 2002 (Cth).

180 These grounds were (i) that an organisation is an incorporated or unincorporated body that directly or indirectly engages in, prepares, plans, assists or fosters the doing of a terrorist act or (ii) an organisation that has been specified by regulation (as a form of proscription) upon ministerial satisfaction on reasonable grounds that the UN Security Council has made a decision relating in whole or part to terrorism and that the organisation is identified in the decision, or using a mechanism established under the decision, as an organisation to which the decision relates.

${ }^{181}$ The Criminal Code Act 1995 (Cth) was amended in 2002 to create a variety of offences. These offences include strict liability offences relating to membership, directing the activities of, funding, assisting or providing training to proscribed organisations: Criminal Code Act 1995 (Cth) ss 102.4(1)(a)(e). Other offences were based on an intention to perform identified actions with the knowledge that the organisation is a terrorist organisation: Criminal Code Act 1995 (Cth) ss 102.2(1), 102.4(1), 102.5(1), $102.6(1)$ and 102.7 (1)) and, in the alternative, an intention to perform identified actions and recklessness as to whether the organisation is a terrorist organisation: Criminal Code Act 1995 (Cth) ss 102.2(2), 102.4(2), 102.5(2), 102.6(2) and 102.7 (2). The identified actions include direction, recruitment, provision or receipt of terrorist organisation training, funding and providing support to terrorist organisations. Where membership of a terrorist organisation is alleged, only the higher standard of intention and knowledge applies, and a separate defence is available on the balance of probabilities that all reasonable steps were taken to cease membership of the organisation as soon as practicable after the person knew that the organisation was a terrorist organisation. See Carne, above n 11, 15-16.

${ }^{182}$ The criterion being that the Minister must be satisfied on reasonable grounds that the organisation is directly or indirectly engaged in, preparing, planning assisting in or fostering the doing of a terrorist act (proposed Criminal Code Act 1995 (Cth) s 102.1 (2) offence).

${ }^{183}$ See Ruddock, above $\mathrm{n} 1$ and Ruddock, above $\mathrm{n}$ 80. The second of these arguments is consistent with the Commonwealth Government's Review of Interactions with the United Nations Treaty Committee System: see Joint Media Release Minister for Foreign Affairs, Attorney-General and Minister for Immigration and Multicultural Affairs, 'Improving the Effectiveness of United Nations Committees', 29 August 2000

<http://www.dfat.gov.au/media/releases/foreign/2000/fa097_2000.html> (7 February 2001) and 'Austra lian Initiative to Improve the Effectiveness of the UN Treaty Committees' 5 April 2001

<http://www.dfat.gov.au/media/releases/foreign/2001/fa043a_01.html> (7 February 2002). See also generally Spencer Zifcak, Mr Ruddock Goes to Geneva (2003); Dianne Otto, 'From 'reluctance' to 'exceptionalism': the Australian approach to domestic implementation of human rights' (2001) 26 Alternative Law Journal 219 and David Kinley and Penny Martin, 'International Human Rights at Home: Addressing the Politics of Denial' (2002) 26 Melbourne University Law Review 466.
} 
guards cited. ${ }^{184}$ These minimal safeguards comprised the capacity to seek an order of review in the Federal Court or the Federal Magistrates Court under the ADJR Act $(\mathrm{Cth})^{185}$ relating to a ministerial decision to proscribe an organisation, as well as Senate disallowance of the relevant regulations, ${ }^{186}$ a politically dangerous response.

These incursions on political freedoms, the retraction of proper public critique and the contours of public debate by this dangerous model of executive proscription, were reflected in the change in Opposition policy to a sanguine acceptance of the executive proscription model, ${ }^{187}$ abandoning its previously advocated judicial proscription model. ${ }^{188}$ Its rejection is both remarkable and ahistorical, as the risks of the misuse of an executive proscription model were formerly canvassed in some detail. ${ }^{189}$ However, the executive model was adopted in the passage of the Criminal Code Amendment (Terrorist Organisations) Act 2004 (Cth) on 4 March 2004, with the Opposition misleadingly claiming that 'robust safeguards' ${ }^{190}$ had been incorpo-

\footnotetext{
${ }^{184}$ See 'A-G Discusses Bill to Ban Terror Organisations and Recall Of The Senate': Transcript radio interview ABC 666 Canberra 5 November 2003

<http://www.ag.gov.au/www/ministerruddockhome.nsf/Web+Pages/BF7B5AADE46B> (5 November 2003).

${ }^{185}$ See Administrative Decisions (Judicial Review) Act 1977 (Cth) ss 5, 6 and 7. S.19 (1) allows the making of regulations declaring that a class or classes of decisions to be decisions that are not subject to judicial review by the Federal Court or the Federal Magistrates Court under the Act. It is therefore feasible that decisions relating to the proscription of organisations under Criminal Code (Cth) Division 102 could be wholly, partly, or incrementally excluded from review under the Administrative Decisions (Judicial Review) Act 1977 (Cth), leaving only such judicial review before the High Court as constitutionally mandated by s 75 (v) of the Australian Constitution and explained in Plaintiff S157/2002 v Commonwealth (2003) 195 ALR 24. The exclusion under the Administrative Decisions (Judicial Review) Act 1977 Schedule 1 of decisions made under the ASIO Act 1979 (Cth) and also under the Intelligence Services Act 2001 (Cth) as decisions to which the Act does not apply, further reduces the scope of judicial review of proscription decisions, as the advice by ASIO to the Attorney General will necessarily be a prelude to the administrative act of ministerial proscription under Division 102 of the Criminal Code (Cth). Similarly, the Freedom of Information Act 1982 (Cth) s.7 and Schedule 2 Part 1 operate to exclude intelligence agency documents preparatory to the act of Ministerial proscription from being subject to freedom of information provisions.

${ }^{186}$ See Acts Interpretation Act 1901 (Cth) s 1 (c) and ss 2 to 5A. A Government majority in the Senate from 1 July 2005, following the 9 October 2004 Federal election, effectively removes this "safeguard" and confirms the originally highlighted dangers of executive proscription.

${ }^{187}$ See Steve Lewis, 'Security alert for Labor', The Australian, 20-21 December 2003, 24. The ruthlessly political nature of this about face is evidenced by the Opposition's resistance to conferring an Executive power of proscription only a month earlier: see Senate, Hansard, 7 November 2003, 16822 on debate about the Criminal Code Amendment (Hamas and Lashkar-E-Tayyiba) Bill 2003 (Cth) (Senator Hon John Faulkner).

${ }^{188}$ See House of Representatives, Hansard, 5 November 2003, 21955 (Robert McClelland).

${ }^{189}$ See House of Representatives, Hansard, 5 November 2003, 21955-21956 (Robert McClelland). See also comments on the risks of executive proscription in House of Representatives Hansard 5 November 2003, 21960 (Hon Duncan Kerr) and in Senate, Hansard, 7 November 2003, 16822-16823 (Senator Hon John Faulkner). See also Head, above n 123, 124 and Hocking, above n 17, 211.

${ }^{190}$ See Senate, Hansard, 3 March 2004, 20519. The extremely limited 'safeguards' comprise a briefing of the Leader of the Opposition of the proposed regulation; a process whereby the Minister must consider a de-listing application made on the ground that there is no basis for the Minister to be satisfied that the listed organisation is directly or indirectly engaged in, preparing, planning, assisting in or fostering the doing of a terrorist act; a discretion (not obligation) for the Parliamentary Joint Committee on ASIO, ASIS and DSD to review the regulation proscribing a terrorist organisation and to report the Committee's comments and recommendations to each House of Parliament before the end of the applicable
} 
rated within the amended legislation. The highly partisan character that the debate about further expansion of counter-terrorism powers has taken was reflected by the starkly contrasting appraisals of the content of the safeguards and the reasons for the passage of the legislation, by the Attorney-General ${ }^{191}$ and the Opposition Spokesperson for Homeland Security. ${ }^{192}$

The merits based judicial proscription model, under which an application would be made to a court for listing of a terrorist organisation, had previously been rejected by the Attorney-General on strongly asserted executive grounds. ${ }^{193}$ The judicial proscription model was considered, by erroneous and inverted reasoning, to infringe the doctrine of the separation of powers:

I cannot imagine anything that might infringe the separation of powers doctrine more than what is being proposed here by the opposition - that I, that you hand over to a judicial body the decision as to whether or not a body ought to be proscribed. ${ }^{194}$

The factors central to a court's role in a judicial proscription model, namely the assessment of rights and duties, the characterisation and weighing of evidence, the interpretation of legislation and the reaching of a determination contingent to the operation of consequences, are characteristics of a kind consistently identified by the High Court as being intrinsic to the exercise of Chapter III judicial power. ${ }^{195}$ Such an error displays both the centrality of executive control of the reforms and a noticeable misunderstanding of the separation of powers under the Australian Constitution.

disallowance period for that House; and a review of the listing provisions by the Parliamentary Joint Committee as soon as possible three years after their commencement: see Schedule 1- Amendments of the Criminal Code Amendment (Terrorist Organisations) Act 2004 (Cth), inserting new ss 102.1 (2), (2A), (4), (5), (6), (17), (18), and 102.1A (1)-(4) into the Criminal Code Act 1995 (Cth).

${ }^{191}$ The Attorney General contested the claim that the Opposition had succeeded in obtaining additional safeguards: House of Representatives, Hansard, 4 March 2004, 25372.

192 See the comments House of Representatives, Hansard, 4 March 2004, 25372-25373 (Robert McClelland). See also Senate, Hansard, 3 March 2004, 20522-20523 (Senator Hon John Faulkner). Importantly, the ex post facto judicial review process is dependent upon the operation of the ADJR Act 1977 (Cth) attaching to the Criminal Code Amendment (Terrorist Organisations) Act 2004 (Cth), as discussed above. Furthermore, the process of consultation with state and territory leaders prior to the listing of an organisation has not been incorporated into the amending legislation.

${ }^{193}$ See House of Representatives, Hansard, 4 November 2003, 21844-21845 (Hon Philip Ruddock).

${ }^{194}$ See House of Representatives, Hansard, 5 November 2003, 21973 (Hon Philip Ruddock).

195 See for example, Huddart Parker and Co v Moorehead (1909) 8 CLR 330, 357 (Griffith CJ); $R v$ Trade Practices Tribunal; Ex parte Tasmanian Breweries (1970) 123 CLR 361, 374 (Kitto J); Re Tracy; Ex parte Ryan (1989) 166 CLR 518, 580 (Deane J); Harris v Caladine (1991) 172 CLR 84, 147 (Gaudron J); Brandy v HREOC (1995) 183 CLR 245, 268 (Deane, Dawson, Gaudron and McHugh JJ). 


\section{Selection And Distortion Of Concepts Arising FROM THE BRIGITTE INCIDENT}

Furthermore, this executive claim arising from the Brigitte incident for an expansion of detention and questioning power is based on several false premises, conceptual confusions and selectivity in the presentation of supportive material. Discrete characteristics are identifiable - the strong detention and questioning powers being taken out of an appropriate comparative context; inappropriate jurisdictional comparisons; considerations of French counter-terrorism powers without mention of the systemic human rights abuses separately established in different forums; confusion over criminal law versus intelligence gathering models; reliance on a highly problematic balancing of rights with powers, as well as contradictions in preferred accountability models governing the exercise of executive power. These characteristics will be examined in turn.

\section{A Decontextualising the potency of existing detention and questioning powers}

The characterisation of the ASIO incommunicado detention and questioning powers as substantially limited in comparison with powers available in France, ${ }^{196}$ involves a misleading comparison abstracted from the unprecedented nature of powers identified during the debate preceding passage of the bill. ${ }^{197}$ The changes made from the bill to the legislation are of particular significance. Under the earlier versions of the bill, ASIO was able to obtain warrants for detention and questioning for a relatively short period of 48 hours, ${ }^{198}$ and a federal magistrate or judge had to approve original or subsequent warrants, following a detailed application process by the Director General of ASIO to the Attorney General. A fresh application process satisfying the threshold criteria had to be repeated for further warrants. ${ }^{199}$ However, following a government 'compromise', the legislation provides for a single, seven day warrant in which 24 hours of questioning may take place, with the continuation of questioning beyond successive eight hour intervals determined by the prescribed authority, in place of a fresh warrant being obtained under judicial authority for further questioning.

\footnotetext{
${ }^{196}$ See Ruddock, 'Intelligence delay has Ruddock asking questions', above n 12 and Ruddock, above n 1.

${ }^{197}$ Detention duration and its application to non-suspects were identified as exceeding relevant, recently enacted legislation in comparable jurisdictions such as the United Kingdom, Canada and the United States. The ambit of the government's present claim for further detention powers is highlighted by its December 2002 rejection of the Opposition's questioning model, which itself exceeded powers granted over citizens in these comparable jurisdictions: See House of Representatives, Hansard, 12 December 2002, 10430 and 10565 (Hon Simon Crean) and 10435 and 10569 (Hon Kim Beazley).

${ }^{198}$ See Clauses 34D(2)(b)(i) and 34F(4)(a) of the original version of the bill.

${ }^{199}$ This obligation is implicit Clause 34C(5) (and its note), which required the granting of a warrant only by a Deputy President of the AAT if the continuous period of detention was to exceed 96 hours.
} 
This provides a significant extension of power in expanding detention time, the flexibility of questioning within that detention time and the removal of the external normative producing requirement to seek a fresh detention and questioning warrant every 48 hours $^{200}$ from a judge or federal magistrate, with the independence of tenure under the Australian Constitution and removed from the actual questioning. Devolving authority to the prescribed authority present at the questioning to authorise continuation of questioning and detention enhances a capacity for preventative detention, as a quite modest threshold applies where a subsequent warrant is sought. ${ }^{201}$ In many situations it would be expected that some additional information would be obtained from the preceding 24 hours of questioning over seven days, to comply with the threshold for a further seven day warrant. Furthermore, the second requirement of not currently being in detention imposes no minimum time interval before which a person may be taken back into custody under a second or subsequent warrant. $^{202}$

\section{B Inappropriate inter-jurisdictional comparisons}

The Attorney General's mooted reforms also disregard the fact that common law based legal systems regularly and readily comparable with Australia - such as the United Kingdom, ${ }^{203}$ Canada, $^{204}$ New Zealand ${ }^{205}$ and the United States ${ }^{206}$ - none permits incommunicado detention of its citizens not suspected of any criminal offence for the purposes of counter-terrorism intelligence gathering. The existence of bills of rights in these jurisdictions ${ }^{207}$ has set boundaries to the legislative debate and response about intelligence gathering from individuals for counter-terrorism purposes and has made rights evaluation more prominent in that equation. ${ }^{208}$ Such

\footnotetext{
${ }^{200}$ Instead, a person exercising authority under the warrant 'may request the prescribed authority to permit the questioning to continue' beyond the respective 8 hours or 16 hours: see ASIO Act 1979 (Cth) s $34 \mathrm{HB}(3)$.

${ }^{201}$ The issuing authority must be additionally satisfied that (i) the issue of that warrant is justified by information additional to or materially different from that known to the Director-General at the time the Director-General sought the Minister's consent to request the issue of the last of the earlier warrants issued before the seeking of the Minister's consent to the request for the issue of the warrant requested; and (ii) the person is not being detained...in connection with one of the earlier warrants: ASIO Act 1979 (Cth) s 34D (1A)(b)(i) and (ii).

${ }^{202}$ See ASIO Act 1979 (Cth) s 34D (1A)(ii).

${ }^{203}$ Terrorism Act 2000 (UK) as amended by the Anti-Terrorism, Crime and Security Act 2001 (UK).

${ }^{204}$ Anti-Terrorism Act 2001 (Canada) Act No 41 of 2001.

${ }^{205}$ Terrorism Suppression Act 2002 (NZ).

${ }^{206}$ USA Patriot Act 2001 Public Law No 107-56.

${ }^{207}$ Human Rights Act 1998 (UK); Canadian Charter of Rights and Freedoms 1982 (Constitution Act, 1982 Schedule B to Canada Act 1982 (UK)); New Zealand Bill of Rights Act 1991 (NZ); United States Bill of Rights Amendments I to XXVII of the United States Constitution (Articles in addition to, and amendment of the United States of America, proposed by Congress, and ratified by the legislatures of the several states pursuant to the fifth article of the original constitution).

${ }^{208}$ The report by the UK Committee of Privy Counsellors on the Anti-Terrorism, Crime and Security Act 2001 (UK) is the most recent illustration of this effect: see Privy Counsellor Review Committee, AntiTerrorism, Crime and Security Act 2001 Review: Report, Presented to Parliament pursuant to Section 122(5) of the Anti-terrorism, Crime and Security Act 2001 (2003), Part 4-Immigration and Asylum, 4868. See also George Williams 'National Security, Terrorism and Bills of Rights' (2003) 9 Australian Journal of Human Rights 263, 270 and Williams, above n 19.
} 
bills of rights have exerted some restraint over the tendency of the Executive to elevate its interests at the expense of the interests of proportionality and necessity in counter-terrorism legislative responses.

In contrast, the citation of French detention laws and their extensive scope, deriving from a civil law system, as a paradigm to which Australia should refer for a further enlargement of powers already exceeding comparable common law democracies, is as strikingly radical a proposition as incommunicado detention of non-suspects itself. More remarkable is the highly artificial manner in which the French system has been presented, omitting any consideration of systemically established French human rights abuses in terrorism intelligence gathering

\section{French terrorism laws: sans human rights abuses}

A proposed expansion of ASIO detention and questioning powers, modelled upon the features of the French legal system, which permits three to four years of pre-trial detention for the gathering of evidence by a body of five anti-terrorist magistrates against a terrorist suspect, ignores systemic human rights abuses identified within that system. The inspiration of the French system in the advocacy of extended intelligence gathering detention superficially identifies an elected system of government possessing such powers, therefore making a simplistic equation of 'democracy' as synonymous with human rights observance. ${ }^{209}$

The issues raised by the Attorney-General about thresholds for detention and questioning warrants and the length of detention time are significant because features of the French system provide open opportunities for human rights abuses. That system permits four days of intense questioning in police custody, three days of which is without access to a lawyer, prior to years of investigative detention once a formal investigation by special anti-terrorism magistrates is commenced. During such investigative detention, an exhaustive conspiracy based charge of 'criminal association relating to a terrorist enterprise ${ }^{, 210}$ is frequently used to justify holding suspects for extended periods ${ }^{211}$ of preventative detention. This is the charge that has been filed against Willy Brigitte. ${ }^{212}$

\footnotetext{
209 "But what you do have is an example here of broader powers that an intelligence agency in a developed Western country - namely, France - has in relation to being able to detain and question people": Ruddock, 'Intelligence delay has Ruddock asking questions', above n 12.

${ }^{210}$ One commentator considers this approach as a de-legitimising process, stripping away human rights from terrorism suspects and non-suspects alike, with anti-terrorism measures then leaking into mainstream criminal investigative processes: see Colin Warbrick, 'The Principles of the European Convention on Human Rights and the Response of States to Terrorism' [2002] 3 European Human Rights Law Review 287, 288, 297.

${ }^{211}$ The purpose is often as much for intelligence gathering purposes as for investigation of a particular criminal offence: see Warbrick, above n 210, 299.

${ }^{212}$ Brigitte's lawyer, Harry Durimel, stated 'Association in the aim of committing a terror act...It mean that they are investigating to find, are suspicion of him being in the plot to commit a terror act. OK, because he's in touch or has been in touch with people that are suspecting of being organiser of terror act': Interview with Harry Durimel, above n 3.
} 
The methods for invoking such powers have raised serious concerns about abuse of process. The leading French anti-terrorist magistrate, Jean-Louis Bruguiere, practises the indiscriminate arrest of large numbers of persons, followed by interrogation, in the hope of uncovering genuine terrorist offenders. ${ }^{213}$ In one instance this led to a large number of defendants subjected to prolonged detention, only subsequently to have charges dropped, be acquitted or receive suspended sentences. ${ }^{214}$ In its 2001 annual report, Amnesty International observed:

The methods of France's specialised "anti-terrorism" investigative judges and the $14^{\text {th }}$ section of the Paris prosecution service continued to be brought into question by a number of court decisions, particularly with regard to the abusive use of provisional detention and to a catch-all conspiracy charge "criminal association with a terrorist enterprise" 215

These criticisms refer to the detention powers that the Attorney General has looked favourably upon as a model for expanding Australian intelligence gathering detention powers.

\section{French terrorism laws: findings of breaches of the European Convention on Human Rights}

France's anti-terrorism laws have also been found to breach articles of the European Convention on Human Rights. In Tomasi v France, ${ }^{216}$ Tomasi, a French national who was a member of Corsican independence organisation, was detained under anti-terrorism laws, for a period of five years and seven months. ${ }^{217}$ The European Court of Human Rights found violations of Articles 5(3), ${ }^{218} 3^{219}$ and $6(1)^{220}$ of

\footnotetext{
${ }^{213}$ Known as the "Bruguiere method": see Henri Astier, 'Profile: France's top anti-terror judge', BBC News Online, 1 July 2003 <http://news.bbc.co.uk/2/hi/europe/3031640.stm> (19 November 2003) and Jocelyn Noveck, 'France's anti-terrorism judge tracks suspects across the globe', Arizona Daily Star, 4 December 2001 <http://www.azstarnet.com/attack/indepth/id-frenchjudge.html> (19 November 2003).

${ }^{214}$ See Amnesty International Report 2001: France

<http://www.web.amnesty.org/web/ar2001.nsf/webeurcountries/FRANCE?OpenDocu> (19 November 2003) under the heading 'Islamist network' trials.

${ }^{215}$ Amnesty International Report 2001: France, above n 214. The report particularly criticised the use of the conspiracy charge of criminal association with a terrorist enterprise, one example of the broad application of this charge resulting in 55 acquittals out of 138 persons charged, and in another 16 out of 24 suspected members of a suspected Islamist network were acquitted of the conspiracy charge. The 2004 Amnesty International Report for France notes that detainees continue to face lengthy provisional detention and that a law on organised crime aimed to extend the 96 hour special custody regime to a wider range of offences: < http://web.amnesty.org/report2004/fra-summary-eng> (28 May 2004).

${ }^{216}$ Case Number 27/1991/279/350 European Court of Human Rights.

${ }^{217}$ The time includes detention during the course of judicial proceedings leading to his acquittal.

${ }^{218}$ Article 5(3) states that 'Everyone arrested or detained in accordance with the provisions of paragraph 1.c of this article shall be brought promptly before a judge or other officer authorised by law to exercise judicial power and shall be entitled to trial within a reasonable time or to release pending trial'.

${ }_{219}$ Article 3 states that 'No one shall be subjected to torture or to inhuman or degrading treatment or punishment'.
} 
the Convention. In relation to Article 5(3), it was found that the French courts failed to act with the necessary promptness, the length of the contested detention not essentially attributable either to the complexity of the case or to Tomasi's conduct. ${ }^{221}$ In relation to Article 3 , Tomasi's complaint of injuries inflicted in detention consistent with the records of complaint made to an investigating judge and the reports of four examining doctors at the end of his police custody, ${ }^{222}$ comprising sustained ill treatment. ${ }^{223}$ These records were in the opinion of the Court sufficient to find that the treatment was both inhuman and degrading, ${ }^{224}$ with 'the undeniable difficulties inherent in the fight against crime, particularly in regard to terrorism, cannot result in limits being placed on the protection to be afforded in respect of the physical integrity of individuals'. ${ }^{225}$ In relation to the alleged violation of Article $6(1)$, namely Tomasi's complaint of the time taken to examine his claim of the ill treatment suffered during police custody, responsibility for the delays was found by the Court to lie essentially with the judicial authorities, thus establishing a violation of Article 6(1).

These types of abuses within the French system of the investigation of terrorism suspects are facilitated by the provision of broader anti-terrorism powers and discretions superimposed on a criminal investigative system for non-terrorism offences, which itself has been the subject of serious breaches of the European Convention of Human Rights. In Selmouni v France, ${ }^{226}$ Selmouni, a Netherlands and Moroccan national, was arrested on suspicion of involvement in drug trafficking and subjected to prolonged and severe ill treatment in police custody. The European Court of Human Rights found that the acts complained of constituted torture under Article 3 of the Convention. ${ }^{227}$ In particular, the Court found that physical and mental pain and suffering was intentionally inflicted for the purpose of obtaining a confession; ${ }^{228}$ that the acts ${ }^{229}$ were sufficient to arouse feelings of fear, anguish and inferiority capable of humiliating and debasing him and possibly breaking his physical and moral resistance; ${ }^{230}$ and that the intensity and frequency of the physical and

\footnotetext{
${ }^{220}$ Article 6(1) states that 'In the determination of his civil rights and obligations or of any criminal charge against him, everyone is entitled to a fair and public hearing within a reasonable time by an independent and impartial tribunal established by law. Judgment shall be pronounced quickly but the press and public may be excluded from all or part of the trial in the interests of morals, public order or national security in a democratic society, where the interests of juveniles or the protection of the private life of the parties so require, or to the extent strictly necessary in the opinion of the court in special circumstances where publicity would prejudice the interests of justice.'

${ }^{221}$ See Tomasi $v$ France paragraph 102.

222 Ibid $108,110$.

${ }^{223}$ This ill treatment persisted for a period beyond forty hours by those responsible for his interrogation: Tomasi v France paragraph 108.

${ }^{224}$ Ibid 115.

${ }^{225}$ Ibid 115.

${ }^{226}$ European Court of Human Rights Application No 25806/94 28 July 1999.

${ }^{227}$ Selmouni v France paragraph 106.

${ }^{228}$ Ibid $\mathrm{I} 98$.

${ }^{229}$ The Court was satisfied that these acts included a large number of blows in repeated and sustained assaults over a number of days of questioning, but also included a range of other serious abuses: Selmouni v France paragraphs 102 and 103.

${ }^{230}$ Selmouni $v$ France paragraph 99.
} 
mental violence, caused severe pain and was particularly serious and cruel. ${ }^{231}$ Such a culture of human rights abuse is even more likely to be propagated in terrorism investigation matters, where access to lawyers is further curtailed ${ }^{232}$ and detention is protracted $^{233}$ with relatively weak review mechanisms. ${ }^{234}$

\section{E French terrorism laws: United Nations findings of breaches of human rights}

United Nations human rights treaty body committees have also commented adversely on the operation of France's anti-terrorism laws and policies. Specifically, the Human Rights Committee, in its concluding observations on the third periodic report of France under the International Covenant of Civil and Political Rights, made several pointed criticisms:

The Committee is concerned about the continued application of the antiterrorist laws of 2 September 1986 and 16 December 1992 which provide for a centralized court with prosecutors having special powers of arrest, search and prolonged detention in police custody for up to four days (twice the normal length), and according to which an accused does not have the same rights in the determination of guilt as in the ordinary courts. The Committee is furthermore concerned that the accused has no right to contact a lawyer during the initial 72 hours of detention in police custody. The Committee is concerned that there is no appeal provided for against the decisions of this special court. The Committee regrets that the State party did not provide information about which authority in practice takes the decision whether a case is handled under the ordinary criminal law or under anti-terrorist laws, and about the role played by police in this decision. The Committee has now been given information as regards statistics on trials concluded under the anti-terrorism laws, but it is informed that many hundreds of people are being detained, investigated and tried for committing acts of terrorism or related offences. Therefore in the circumstances, the Committee would recommend that anti-terrorism laws, which appear to be

\footnotetext{
${ }^{231}$ Ibid paragraphs 104 and 105.

${ }^{232}$ France's representations at consideration of its second periodic report under the Convention Against Torture revealed that changes allowing access to a lawyer during the first hour of custody 'were not envisioned to apply to acts of terrorism': Summary Record of $320^{\text {th }}$ meeting: Committee Against Torture UN Document CAT/C/SR.320 14 September 1998, paragraph 7. There is no right to contact a lawyer during the initial 72 hours of detention in police custody: see Concluding observations of the Human Rights Committee: France 4 August 1997 UN Document CCPR/C/79/ Add.80, paragraph 23.

${ }^{233}$ Initial detention in police custody is for up to four days, twice the normal length of detention: Concluding observations of the Human Rights Committee: France 4 August 1997 UN Document CCPR/C/79/Add.80, paragraph 23.

234 'The Act of Parliament of 30 December 1996 on terrorism related pre-trial detention...strengthened safeguards for persons under investigation, in particular by limiting the use of pre-trial detention, which could not exceed a 'reasonable' period based on the gravity of the alleged acts: the judge must end detention once it exceeded a reasonable period': submission of France, Summary Record of $320^{\text {th }}$ meeting: Committee Against Torture UN Document CAT/C/SR.320 14 September 1998, paragraph 9.
} 
necessary to combat terrorism, be brought fully into conformity with the requirements of articles 9 and 14 of the Covenant. ${ }^{235}$

Three other human rights issues, significant in the light of France's counterterrorism legislation and policies, were highlighted by the Committees. The first was repeated allegations of violence and ill treatment of detainees by law enforcement officials, ${ }^{236}$ likely to be exacerbated by the reduced rights accorded to persons detained for terrorism offences, with foreigners and immigrants particularly vulnerable. $^{237}$ The second area of concern was the frequency and length of pre-trial detention. $^{238}$ The third item, namely France's repatriation of terrorism suspects to demonstrated situations of potential torture, ${ }^{239}$ reinforces preceding evidence of an inadequate human rights attitudinal and procedural framework in investigating terrorism offences. A most exceptional aspect was the extra-judicial repatriation of suspects from the French to the Spanish police, a 'practice whereby the police hand over individuals to their counterparts in another country, despite the fact that a

${ }^{235}$ Concluding observations of the Human Rights Committee: France 4 August 1997 UN Document CCPR/C/79/Add.80, paragraph 23. Article 9 of the ICCPR includes a range of due process rights such as liberty and security of the person, freedom from arbitrary arrest or detention, the establishment of lawful grounds for arrest and arrest procedures, the right to be brought promptly before a judge, the right to take proceedings before a court to decide the lawfulness of detention and an enforceable right to compensation for anyone who has been the victim of unlawful arrest or detention. Article 14 of the ICCPR includes a range of due process rights relating to pre-trial and trial matters.

${ }^{236}$ See Concluding observations of the Human Rights Committee: France 4 August 1997 UN Document CCPR/C/79/Add.80, paragraph 16; Committee Against Torture Summary record of the public part of the $323^{\text {rd }}$ meeting: France 11 May 1998 UN Document CAT/C/SR.323 D. Subjects of Concern, paragraph 5; Concluding observations of the Committee against Torture: France 27 May 1998 UN Document A/53/44, paragraph 143 (e)

${ }^{237}$ Concluding observations of the Human Rights Committee: France 4 August 1997 UN Document CCPR/C/79/Add.80, paragraph 16.

${ }^{238}$ Concluding observations of the Human Rights Committee: France 4 August 1997 UN Document CCPR/C/79/Add.80, paragraph 17. The French delegation claimed improvements in relation to these issues, with 34 per cent of persons under investigation subject to pre-trial detention in 1994, compared to 44 per cent in 1985, whilst also stating that "A new law, which had entered into force on 31 March 1997, was aimed at reducing the length of pre-trial detention... That law... was not the first effort made to reduce the period of pre-trial detention, the Act of 6 August 1995 having already imposed a limit": Human Rights Committee Summary record of the $1597^{\text {th }}$ meeting: France 24 July 1997 UN Document CCPR/C/SR.1597, paragraph 53. See also Committee Against Torture Summary record of the $320^{\text {th }}$ meeting: France UN Document CAT/C/SR.320, paragraph 9. In contrast, more stringent review requirements were imposed on other criminal offences.

${ }^{239}$ See Concluding observations of the Committee against Torture: France 27 May 1998 UN Document A/53/44, paragraph 143 (d); Human Rights Committee Summary record of the $1598^{\text {th }}$ meeting: France 20 October 1997 UN Document CCPR/C/SR.1598 paragraph 29. Such deportation involves a potential violation of States Parties obligations under Article 3 of the Convention Against Torture, which states ' 1. No State party shall expel, return (refouler) or extradite a person to another State where there are substantial grounds for believing that he would be in danger of being subjected to torture. 2. For the purpose of determining whether there are such grounds, the competent authorities shall take into account all relevant considerations including, where applicable, the existence in the State concerned of a consistent pattern of gross, flagrant or mass violations of human rights'. 
French court has declared such practices to be illegal'. ${ }^{240}$ In the communication of Arana $v$ France, ${ }^{241}$ the Committee Against Torture recalled that:

[D]uring the consideration of the third periodic report submitted by Spain...it had expressed its concern regarding the complaints of acts of torture and ill treatment which it frequently received. It also noted that, notwithstanding the legal guarantees as to the conditions under which it could be imposed, there were cases of prolonged detention incommunicado, when the detainee could not receive the assistance of a lawyer of his choice, which seemed to facilitate the practice of torture. Most of the complaints received concerned torture inflicted during such periods. ${ }^{242}$

The Committee found that the deportation to Spain occurred in circumstances constituting a violation of Article 3 of the Convention:

The deportation was effected under an administrative procedure, which the Administrative Court of Pau had later found to be illegal, entailing a direct handover from police to police, without the intervention of a judicial authority and without any possibility for the author to contact his family or his lawyer. That meant that a detainee's rights had not been respected and had placed the author in a situation where he was particularly vulnerable to possible abuse. $^{243}$

It is improper to raise the desirability of liberalising Australia's counter-terrorism detention and questioning laws by highlighting the supposed superiority of the French system, whilst abstracting from that discussion a record of serious human rights violations. Adoption of the central features of the French system would transform Australian laws to a dragnet method of terrorism intelligence gathering and an acceptance that innocent detained persons must inevitably experience serious human rights violations. The certainty and regularity of such violations should be honestly and directly confronted in the "balance" paradigm when advocacy of the French model is used in favour of liberalising the availability and duration of Australian counter-terrorism detention and questioning warrants and the relaxation or removal of warrant application safeguards.

\footnotetext{
${ }^{240}$ See Concluding observations of the Committee against Torture: France 27 May 1998 UN Document A/53/44 paragraph 143 (d) and Summary record of the public part of the $323^{\text {rd }}$ meeting: France 11 May 1998 UN Document CAT/C/SR.323 paragraph D 4.

${ }^{241}$ Committee Against Torture Communication No 63/1997.

${ }^{242}$ Committee Against Torture Communication No 63/ 1997 UN Document CAT/C/23/D/63/1997 paragraph 11.4

${ }^{243}$ Committee Against Torture Arana v France Communication No 63/1997: France 5 June 2000 UN Document CAT/C/23/D/63/1997 paragraph 11.5.
} 


\section{F Creating or Creative Confusion? Criminal Law versus In- telligence Gathering Models}

The difficulties identified in the French system are further compounded by confusions over criminal law versus intelligence gathering models for counter-terrorism detention and questioning powers. In its evidence before Parliamentary Committee enquiries into the ASIO Legislation (Terrorism) Amendment Bill 2002 (Cth), the Attorney-General's department justified its support for the far reaching impact upon the rights of innocent persons who may have information relating to terrorist activity, on the basis that the bill was an intelligence gathering model, as distinct from a criminal investigative model. The new threat of international terror demanded a fresh paradigm, abandoning reasonable suspicion of criminal involvement as a central operating principle, and substituting instead an intrusive ability to gather intelligence from non suspects and suspects alike. Rhetorical justifications claimed that differentiated intelligence gathering models, such as those in the United Kingdom and Canada, had been considered but were unsuitable for Australian circumstances. $^{244}$

The unarticulated foundation of the Attorney-General's claim for an expanded detention and questioning regime modelled on the French system is, ironically, a criminal law investigative model. Of course, the French system of extended detention of terrorist suspects is premised on the civil law concept of the investigating magistrate for criminal matters, and in its relevant manifestation upon a broad, catch all terrorism conspiracy-involvement holding charge. ${ }^{245}$ It would not be surprising if reform proposals from the department internal review of the legislation follow a similar approach, discounting previous departmental strictures against a criminal law model for an intelligence gathering function. ${ }^{246}$

This differentiation of criminal law and intelligence gathering purposes for detention and questioning warrants is also selective and highly opinionated, as the two categories seem confusingly distinguished to rationalise expansions in executive questioning and detention power. On the one hand, the supposed differences provide the reasons for rejecting more restricted intelligence gathering models from comparable jurisdictions:

The major cornerstones of consideration were the obvious culprits - the United Kingdom, the United States, Canada and New Zealand. The legislation from those jurisdictions was in fact considered in the drafting of this legislation, but there were two very distinct differences in some of that legislation. One was that most of that legislation is law enforcement based...we took the view that this was about intelli-

\footnotetext{
${ }^{244}$ See Senate Legal and Constitutional References Committee Hansard 12 November 2002, 3-4.

${ }^{245}$ See Astier, above n 213.

${ }^{246}$ Although the Anti-Terrorism Act (No 2) 2004 (Cth) did not include amendments to the s 34D warrant provisions of the ASIO Act 1979 (Cth), its inclusion of a broadly based offence of associating with terrorist organisations as s.102.8 in Part 5.3 of the Criminal Code (Cth) as a 'terrorism offence', within that meaning in s.4 of the ASIO Act 1979 (Cth), will significantly expand the situations in which the warrant request and issue procedures might be invoked.
} 
gence collection and not law enforcement, before the event rather than after the event, we then went outside the parameters or looked outside the square to see how ASIO as an agency might deal with those matters...In terms of the discrepancies, I think it is fair to say...that in the United Kingdom, for example, yes, it is a law enforcement technique that they have there...I think there is a similar provision in Canada...Again I go back to the comment I made earlier, that those laws were drafted in the context of law enforcement agencies investigating an offence. ${ }^{247}$

This apparent confusion of principle appeared in other evidence before the Senate Legal and Constitutional References Committee:

Having looked at Dr Carne's submission and his supplementary submission to the committee, as best as I can understand what he is driving at I still think there is a fundamental distinction between Dr Carne's proposal and what has been proposed in the bill - and that, again, is the distinction between doing things broadly for a law enforcement purpose for the investigation of criminal offences or the gathering of criminal intelligence and what has been proposed under the bill for the gathering of intelligence for security purpose in relation to terrorism. ${ }^{248}$

In sharp contradistinction, the legal arrangements in the UK and Canada are invoked later on to argue that the detention procedures for non-suspects under the Australian bill cannot be compared to legislation used in Malaysia, Singapore and South Africa. In contrast, the Australian proposals are seen as properly comparable on this occasion with the UK and Canada:

Others would disagree, but I think you would be drawing a long bow to see the powers in Malaysia and Singapore and these powers as similar. You could look at the UK and Canada, where there are similar common law principles to those that instruct our legal framework. Ultimately, it is our rule of law, it is the totality of the legal system that would separate us from other countries that might have powers of detention. For proper parallels, I believe you would need to go to countries, as I have said, such as the UK

\footnotetext{
${ }^{247}$ Senate Legal and Constitutional References Committee, Hansard, 12 November 2002, 3-4.

${ }^{248}$ Senate Legal and Constitutional References Committee, Hansard, 18 November 2002, 107. The evidence presented before the Senate Legal and Constitutional References Committee clearly expounded an alternative intelligence gathering model based on the Canadian investigative hearing model under Part II. 1 of the Canadian Criminal Code, adapted for Australian constitutional circumstances, similar to the Canadian investigative hearing, and did not proceed from a criminal law model. See Senate Legal and Constitutional References Committee, ASIO Legislation Amendment (Terrorism) Bill 2002 (Cth), Submissions 24 and 24A and witness submission Senate Legal and Constitutional References Committee, Hansard, 14 November 2002, 90-104. Ironically, further observations were made about the 'clear distinction between the criminal process and the security intelligence process': Senate Legal and Constitutional References Committee, Hansard, 18 November 2002, 111. This confusion prompted former legal academic and Committee member, Senator Linda Kirk, to observe 'I am still trying to get my head around the distinction between intelligence gathering and criminal investigation': Senate Legal and Constitutional References Committee, Hansard, 18 November 2002, 119.
} 
and Canada, which do share with us a common law system and the principles involved. $^{249}$

These later observations contradict the earlier rationales advanced by the AttorneyGeneral's department. This inconsistent invocation and blurring of principle prompted the representative of the Australian Law Council to remark to the Senate Legal and Constitutional References Committee:

The question of principle is most clearly focused in this quite disturbing elision and confusion of concept advanced by ASIO, maybe by the AFP and certainly by the government in relation to what might be called 'prophylactic detention', which is nonsense. It is the notion that detention for the purpose of questioning also has the legitimate purpose of keeping somebody incommunicado from the people who might be their cohorts in a wicked endeavour so as to either prevent the crime from being committed or to prevent that person from assisting in that crime. This is to confuse the notion of non-suspects being questioned with the notion that somebody suspected of being a conspirator - that is, having already committed a serious offence - should be charged. Such a person, in the ordinary course, would no doubt be denied bail. That is a totally different, orthodox method. No one calls that prophylactic detention. Bail is not for the purpose of preventing somebody from committing an offence, but it is to make sure that they are available to answer the requirements of criminal justice. $^{250}$

The fact that there is no rigid barrier to dual usage of information obtained ${ }^{251} \mathrm{em}^{-}$ phasises the convenience in the distinctions claimed.

\section{G Imbalances in the balancing model}

Such usages are more than an elision of principles. Instead, they suggest that the "balancing" model of powers and rights, which the Attorney General claims in relation to the Brigitte incident, has produced too many checks and balances, ${ }^{252}$ is fundamentally flawed. The preceding material suggests that the balancing para-

\footnotetext{
${ }^{249}$ Senate Legal and Constitutional References Committee, Hansard, 18 November 2002, 120.

${ }^{250}$ Brett Walker SC, Member, Law Council of Australia and President of the NSW Bar Association Senate Legal and Constitutional References Committee, Hansard, 26 November 2002, 247.

${ }^{251}$ Whilst use immunity is applied to information obtained or things or records produced, there is no derivative use immunity under the legislation: see ASIO Act 1979 (Cth) s 34G (9)(a) and (b). A relevant example was the attempt to charge two alleged Brigitte associates, with the use of relevant ASIO intelligence restricted to an evidentiary resource from which the police could build a case on the charges using other methods: see Martin Chulov, 'Brigitte suspects: police thwarted', The Australian, 9 February 2004, 1.

252 'Our laws, because of the efforts to put in place checks and balances, may have been too checked...' Hon P Ruddock comments to ABC Radio reported in 'Australian to Review Anti-Terror Laws with Eye on Stronger Powers', 3 November 2003 <http://sg.news. yahoo.com/031103/1/3fjdb.html> (21 November 2003).
} 
digm, applied to proposals to broaden the availability and duration of warrants, is susceptible to arguments diminishing civil and political rights without coherently integrating an intelligence gathering mechanism within a framework securing the institutions, values and practices of democracy. Accordingly, the balancing model encounters problems in addressing national security issues in general and "balance" references relating to warrant powers need to be more sceptically considered within that broader question.

Information called to support "balance" issues justifying an expansion of warrant powers is presupposed as factually accurate, legally accessible and open to systematic critique in the media and in parliamentary processes. Instead, the very secrecy of intelligence gathering measures against terrorism is at odds with these characteristics and reflects the practical impossibility of testing the veracity of the national security policy claim. The model of competition and conflict between the values produces an ascendancy of national security values over civil rights values, and does so under the guise of a supposedly neutral process. In effect, civil rights values are relegated to a residual or negative form of liberty as against national security prerogatives, with considerable discretion and deference afforded to executive interests. The national security aspect in the balance is inevitably given special weighting, producing a structural inequality in that "balance".

These considerations suggest a general unsuitability of the balancing paradigm for reconciling national security and democratic interests, even more so in the situation of warrant intelligence gathering and detention powers applied to innocent persons. This unsuitability is evident in that traditionally, the balancing theory only demanded modest rights concessions in response to modest threats, whereas the indeterminate nature of the war on terror raises the prospect of a decades long corrosion of rights and freedoms. ${ }^{253}$ Adherence to human rights definitive of liberal democratic societies threatened by terrorism is also important because such adherence may produce more efficient law enforcement outcomes. ${ }^{254}$

\section{H Contradictions in the preferred accountability models}

The Attorney General's suggestion from the Brigitte incident that the ASIO detention and questioning warrant requirements have been too rigorously set disconnects that threshold from the Government's preferred human rights accountability model expressed elsewhere. The government's rejection of a judicially supervised bill of rights as a foundation for the protection of human rights has been justified on the grounds of a strong tradition of representative Parliamentary democracy, the rule of law and Australia's unique common law, statutory and constitutional arrangements. ${ }^{255}$ Inevitably, the secrecy and anonymity of the measures involved in the

\footnotetext{
${ }^{253}$ Kerr, above n 58, 2.

${ }^{254}$ See Bronnitt, above n 31, 80

${ }^{255}$ See, for example, A-G's Press Release 'UN Human Rights Committee' 29 July 2000

<http://www.law.gov.au/aghome/agnes/2000newsag/796_htm > (7 July 2001) [in asserting the Austra
} 
detention and questioning warrants, means that these preferred accountability mechanisms are severely compromised and rendered largely inapplicable.

The reliance upon ministerial responsibility as an accountability mechanism in the operation of detention and questioning warrants throws these issues into sharp focus. The Brigitte incident illustrates how the exclusionary concept of operational matters ${ }^{256}$ acts to inhibit and generalise public scrutiny about intelligence gathering in a manner that dramatically curtails public and parliamentary accountability. Simultaneously, such generalisations can heighten speculation and fear about terrorist threats, changing the political climate for debate and producing a laxity in the scrutiny of proposed reforms.

The concept of operational matters as a broad exclusionary mechanism has been formalised through inclusion in the rushed passage of the ASIO Legislation Amendment Act 2003 (Cth), ${ }^{257}$ strengthening prohibitions against communicating information arising from the issuing of and information obtained from or related to detention and questioning warrants. Operational information is also included as a component of a much more broadly based offence of disclosure of information whilst a warrant is in force, ${ }^{258}$ making media reporting of such operational information, the fact that a warrant has been issued, a fact relating to the content of a warrant or to the questioning or detention of a person in connection with a warrant, a criminal offence punishable by up to five years imprisonment. ${ }^{259}$

Other accountability mechanisms, particularly the role of the issuing authority under the existing criteria, rather than justifying liberalisation, assume a heightened

lian government's discretion about how it implements its international obligations under the International Covenant on Civil and Political Rights]: 'In Australia we do so through a combination of strong democratic institutions, the common law and an extensive array of statutes and programs at the Commonwealth, State and Territory level. This fits our circumstances and is highly effective'; see also Attorney-General's Transcript of Speech, 'Writing the Rights - Does Australia Need a Bill of Rights?'. 28 March 2003:

<http://www.ag.gov.au/ag/agd/WWW/attorneygeneralHome.nsf/Page/Speeches_2003_Spee> (2 No

vember 2004) and the similar statements of Leslie Luck, Permanent Representative to the United Nations Office at Geneva: United Nations Press Release Human Rights Committee $69^{\text {th }}$ session 20 July 2000 and Report of Australia and United Nations Press Release Committee Against Torture $25^{\text {th }}$ session 16 November 2000 Report of Australia.

${ }^{256}$ For example, the Attorney General declined to provide greater specificity about investigations in the Brigitte matter: Ruddock, 'Interview: Philip Ruddock', above n 12 and Ruddock, above n 1. The Director-General of ASIO also declined to comment as to whether the detention and questioning powers had been used in relation to the Brigitte case on the grounds of it being an ongoing operational matter: see Senate Legal and Constitutional Legislation Committee, Hansard, 3 November 2003, 143 and 145 (Senate Estimates hearings). This response reflects a generic approach of neither confirming nor denying the existence or substance of national security matters.

${ }^{257}$ Strict liability offences are created for the disclosure of operational information by persons the subject of a warrant or a lawyer variously involved either at the time of the warrant or subsequently on behalf of the subject, within two years of the end date of a warrant: see ASIO Act 1979 (Cth) s 34VAA (2) and (3)(a) and 3(b)(i), (ii) and (iii). Operational information is broadly defined. See the discussion 'Recent and Prospective Executive Claims For Enhanced Power: ASIO Legislation Amendment Act 2003 (Cth)' above.

${ }^{258}$ See ASIO Legislation Amendment Act 2003 (Cth) ss 34VAA (5).

${ }^{259}$ See ASIO Legislation Amendment Act 2003 (Cth) ss 34VAA (1). 
importance in compensating for these deficiencies. The criteria and the need for judicial approval in a persona designata capacity as the issuing authority provide some qualitative and methodological appraisal of the case supporting a warrant and a degree of independence in assessing that case. Far more stringent criteria were moved as amendments by the minor parties to the bill, ${ }^{260}$ but were rejected by the major parties. These proposed amendments would have provided a clear nexus to actuality or likelihood of the commission or involvement in an actual or prospective terrorism related offence. ${ }^{261}$

The existing criteria reflect, if imperfectly, the previous ministerial and departmental justification that these are warrants of last resort. ${ }^{262}$ The "last resort" principle embodies residual notions of constraint, exceptionality, proportionality and necessity in justifying this drastic paradigm shift to the detention and questioning of innocent persons for intelligence gathering purposes. Indirectly, the "last resort" principle is a practical device in organising intelligence gathering priorities and resource use, encouraging the use of less overtly intrusive methods of intelligence gathering, ${ }^{263}$ as well as promoting a greater focus on analysis, coordination, exchange and extrapolation from information gleaned from existing sources and methods. Adherence to such restraints more closely approximates liberal democratic values.

Relaxation of warrant criteria would institute a more speculative approach to antiterrorism intelligence gathering. Such a development is likely to prove counterproductive as intelligence resources, human and technical, are expended on matters with an increasingly tenuous connection to substantial terrorism offences. Indeed, a major explanation for the delay under the existing legislative arrangements in focusing intelligence efforts on Brigitte's presence in Australia, following an initial

\footnotetext{
${ }^{260}$ See the Australian Democrat proposed amendment to ASIO Legislation Amendment Terrorism Bill 2002 [No 2] (Cth) Amendment Sheet No 292313 June 2003 by Senator Greig adding to the issuing criteria of a questioning and detention warrant and the Greens proposed amendment to the ASIO Legislation Amendment Terrorism Bill 2002 [No 2] (Cth) Sheet No 2957 -rev 17 June 2003 by Senator Nettle proposing a change to the consent process.

${ }^{261}$ See Senate, Hansard, 19 June 2003, 11758 to 11769 for debate on the Australian Democrats amendment and Senate, Hansard, 19 June 2003, 11769 on the Green amendments.

${ }^{262}$ This is particularly reflected in the s $34 \mathrm{C}$ (3)(b) criterion 'that relying on other methods of collecting that intelligence would be ineffective'. Attorney General Williams consistently emphasised the 'last resort' nature of the warrants: see House of Representatives, Hansard, 20 March 2003, 13172 and Williams, above n 46 and A-G's Press Release, 'Final Passage Of ASIO Powers Legislation', 26 June 2003

<http://www.ag.gov.au/www/attorneygeneralHome.nsf/Web+Pages/E8A8FB88011F66> (29 June 2003). Submissions to the Senate Legal and Constitutional References Committee by ASIO and the AttorneyGeneral's Department argued the exceptionality of the 'last resort' application of detention warrants: Senate Constitutional and Legal References Committee, Hansard, 18 November 2002, 110 and 125.

${ }^{263}$ See the ASIO Act 1979 (Cth) ss 25A (Computer access warrant), 26 (listening devices), 26A, 26B and 26C (tracking devices), 27 (inspection of postal articles) and 27AA (inspection of delivery service articles).
} 
and repeated alert from the French authorities, was that it was not seen as a matter of high priority. ${ }^{264}$

\section{Conclusion: A Misguided Reform Paradigm}

In reflecting upon the excesses of the executive branch's reaction to the Brigitte incident, the observations of two High Court judges made in national security contexts are singularly appropriate:

History and not only ancient history, shows that in countries where democratic institutions have been unconstitutionally superseded, it has been done not seldom by those holding the executive power. ${ }^{265}$

It is of the essence of a free society that a balance is struck between the security that is desirable to protect society as a whole and the safeguards that are necessary to ensure individual liberty. But in the long run the safety of a democracy rests upon the common commitment of its citizens to the safeguarding of each man's liberty, and the balance must tilt that way. ${ }^{266}$

The preceding examination of various reform claims for enlarging executive power argues that there is neither a rational nor a substantiated case for the Attorney General's claims to loosen the constraints on the unprecedented detention and questioning powers in the ASIO Legislation (Terrorism) Amendment Act 2003 (Cth).

Implementing such reform proposals will compound recent inroads on fundamental tenets governing the relationship between the citizen and the state, further diminishing critical rule of law principles such as the accountability of institutions, due process, separation of power, scrutiny of authority and constraints on the exercise of discretions. Extending the legislation to further circumstances of non-suspects, demands that a cogent and publicly documented case be established by the executive and rigorously tested in deliberative mechanisms, such as parliamentary inquiries and media analysis. Increases in extraordinary power must also be tempered with the development of new and specific accountability mechanisms and controls ensuring proportion and necessity.

The Brigitte incident has given prominence to the political opportunities and usages of contemporary national security issues, in both a party political sense and through diminutions of legal and political accountability within a democratic polity. It is a case study par excellence of a democracy's susceptibility to a crisis response,

\footnotetext{
${ }^{264}$ Hon P Ruddock House of Representatives, Hansard, 4 November 2003, 21855. See also the evidence of Federal Police Commissioner Mick Keelty before the Senate Estimates hearings: Senate Legal and Constitutional Legislation Committee, Hansard, 3 November 2003, 132-133.

${ }^{265}$ Australian Communist Party v Commonwealth (1951) 83 CLR 1, 187 (Dixon J).

${ }^{266}$ Alister v R (1984) 154 CLR 412, 456 (Brennan J).
} 
precluding mature legislative deliberation, rounded and consultative policy development and asserting that amending legislation must be speedily passed. Significant elements of that crisis response may arise through strategic suggestion, ambivalence and hypotheses in the public communication of counter-terrorism information. The executive invocation of the 'operational information' criterion severely curtails such communication, whilst simultaneously raising a claim for legislative reform. Continual pressure for 'enhancement' of counter terrorism laws overestimates the capacity of legal frameworks to address the threat of terrorism, instead of being considered as one of many components in a holistic framework of domestic, regional and foreign policy counter-terrorism responses.

Executive control is also strengthened in the fact that broader review of legislative reform, by public and expert contributions to a parliamentary committee of inquiry, is undesirable and consultation should be confined to the party room, including, to facilitate passage, consultation within the Opposition party room. ${ }^{267}$ An Opposition's institutional role in seriously appraising and critiquing significant, unpredictable erosions of civil and political rights under broader intelligence gathering powers is equated with weakness and vacillation. Increasingly, the Opposition is coopted into concurrence with Government proposals aggressively undermining rights, as well as attempting to neutralise Government political advantage in this issue, possibly by outbidding the Government in the conferral of executive orientated counter-terrorism powers. Such a development would constitute a mutual conflation of partisan interests with the security of the nation.

Increasingly, the Australian counter-terrorism legislative response can be seen as serially eroding civil and political rights, producing no guaranteed enhancement of security but disproportionately compromising democratic institutions, practices and accountability mechanisms. Such imbalances produced by this "balancing" model of reconciling legal formulations of security and liberty is best explained through several parallel developments. The unifying thread is the heightened assertions of executive authority over public debate and legislative reform, with a willingness to pursue party political and electoral interests as synonymous with the security of the nation.

The fear generated and crystallised by the Brigitte incident has produced an unprecedented legislative suppression of the ability of the media to report on detention and questioning warrants, ${ }^{268}$ where no demonstrated security risk exists and where such reporting constitutes an essential democratic accountability measure. Describing such amendments as merely "technical" exposes a serious vacuum in sophisticated policy development in the fundamental values at stake. Such approaches will inevitably diminish civil and political rights by appeasing every government claim made for an enhancement of power. That appeasement will only encourage both

\footnotetext{
${ }^{267}$ See Hon Philip Ruddock, 'News Conference at Parliament House', Transcript 27 November 2003 <http://www.ag.gov.au/www/ministerruddockhome.nsf/Web+Pages/E80E)CDFA427F8> (5 December 2003)

${ }^{268}$ ASIO Legislation Amendment Act 2003 (Cth).
} 
further governmental claims for expanded powers, as well as an opportunistic testing of the limits of compliance at vulnerable political moments for the Opposition and minor parties. ${ }^{269}$

${ }^{269}$ The characteristics of this appeasement have been variously identified as a lack of commitment to matters of principle, contributing to a pattern of government misrepresentation regarding powers and safeguards in the legislation, and capitulation when serious erosions of civil liberties have been unsatisfactorily addressed: Hocking, above n 17, 220, 226, 227. 